\title{
Geochemical and sedimentological responses of arctic glacial Lake Ilirney, chukotka (far east Russia) to palaeoenvironmental change since $\sim 51.8 \mathrm{ka} \mathrm{BP}$
}

\author{
Stuart A. Vyse ${ }^{\text {a, b, * }}$, Ulrike Herzschuh ${ }^{\mathrm{a}, \mathrm{b}, \mathrm{c}}$, Andrei A. Andreev ${ }^{\mathrm{a}}$, \\ Lyudmila A. Pestryakova ${ }^{\mathrm{d}}$, Bernhard Diekmann ${ }^{\mathrm{a}}$, , Simon J. Armitage e, f, \\ Boris K. Biskaborn ${ }^{\text {a, ** }}$ \\ a Alfred Wegener Institute Helmholtz Centre for Polar and Marine Research, Research Unit Potsdam, Telegrafenberg A45, 14471, Potsdam, Germany \\ ${ }^{\mathrm{b}}$ Institute of Environmental Science and Geography, University of Potsdam, Potsdam, Germany \\ ${ }^{\mathrm{c}}$ Institute of Biochemistry and Biology, University of Potsdam, Potsdam, Germany \\ ${ }^{\mathrm{d}}$ Northeastern Federal University of Yakutsk, Yakutsk, Russia \\ e Centre for Quaternary Research, Department of Geography, Royal Holloway University of London, Egham, Surrey TW20 OEX, UK \\ f SFF Centre for Early Sapiens Behaviour (SapienCE), University of Bergen, Post Box 7805, 5020, Bergen, Norway
}

\section{A R T I C L E I N F O}

\section{Article history:}

Received 21 May 2020

Received in revised form

4 September 2020

Accepted 15 September 2020

Available online $\mathrm{xxx}$

\section{Keywords:}

Arctic

Russia

Late quaternary

Palaeolimnology

Palaeoenvironmetal change

MIS3

XRF

\begin{abstract}
A B S T R A C T
Palaeoenvironmental reconstructions with temporal coverages extending beyond Marine Isotope Stage (MIS) three are scarce within the data sparse region of Chukotka, Far East Russia. The objective of this paper is to infer palaeoenvironmental variability from a $10.76 \mathrm{~m}$ long, OSL- and ${ }^{14} \mathrm{C}$ - dated sediment core from Lake Ilirney, Chukotka $\left(67^{\circ} 21^{\prime} \mathrm{N}, 168^{\circ} 19^{\prime} \mathrm{E}\right)$. We analysed high-resolution sediment-geochemistry (XRF), sedimentology (TC, TN, TOC, grain-size), mineralogy (XRD) and preliminary micropalaeontological data (diatoms and pollen) from the core as well as acoustic sub-bottom profiling data from the lake basin. Our results affirm the application of XRF-based sediment-geochemical proxies as effective tracers of palaeoenvironmental variability within arctic lake systems. Our study reveals that a lake formed during MIS3 from $51.8( \pm 4.1)$ ka BP, following extensive MIS4 glaciation. Catchment palaeoenvironmental conditions during this time remained harsh associated with the continued presence of a catchment glacier until $36.2( \pm 2.6)$ ka BP. Partial amelioration reflected by increased diatom, catchment vegetation and lake organic productivity and clastic sediment input from mixed sources from $36.2( \pm 2.6)$ ka BP resulted in a lake high-stand $\sim 15 \mathrm{~m}$ above present and is interpreted as evidence of a more productive palaeoenvironment coincident with the MIS3 interstadial optimum. A transitional period of deteriorating palaeoenvironmental conditions occurred $\sim 30-27.9$ ka BP and was superseded by periglacial-glacial conditions from $27.9( \pm 0.8)$ ka BP, during the last glacial maximum. Deglaciation as marked by sediment-geochemical proxies commenced at $20.2( \pm 0.8)$ ka BP. Our findings are compared with lacustrine, Yedoma and river-bluff records from across Beringia and potentially yield limited support for a marked Younger Dryas cooling in the study area.
\end{abstract}

() 2020 The Authors. Published by Elsevier Ltd. This is an open access article under the CC BY license (http://creativecommons.org/licenses/by/4.0/).

\section{Introduction}

Recent global climate change poses an existential threat for

\footnotetext{
* Corresponding author. Alfred Wegener Institute Helmholtz Centre for Polar and Marine Research, Research Unit Potsdam, Telegrafenberg A45, 14471, Potsdam, Germany.

** Corresponding author.

E-mail addresses: stuart.vyse@awi.de (S.A. Vyse), Boris.Biskaborn@awi.de (B.K. Biskaborn).
}

Arctic areas (ACIA, 2004; IPCC, 2019). The Arctic region has warmed more than twice as fast as the global average over the instrumental record due to the phenomenon of Arctic amplification (Cohen et al., 2014). This is especially the case in far-east Russia where recent permafrost temperature increases are at their highest rates (Biskaborn et al., 2019c). Dramatic ecological and socio-economic consequences are to be expected (AMAP, 2017; Hope and Schaefer, 2016; Saulnier-Talbot et al., 2014). Consequently, understanding past environmental and climate variability within this region is essential in order to improve constraints on climate 
sensitivity and the prediction of future environmental changes (Biskaborn et al., 2012). Despite significant studies of Holocene and late Glacial palaeoenvironmental variability within records from eastern and northeastern Russia (Biskaborn et al., 2013, 2012; Diekmann et al., 2016; Wetterich et al., 2014, 2011), palaeoenvironmental records that cover this interval within Chukotka, far east Russia are comparatively sparse (e.g. Lozhkin and Anderson, 2011 and references therein). Moreover, Chukotkan records that cover marine isotope stages three (MIS3) and four (MIS4) are particularly desired but currently limited to a handful of sites (Lozhkin and Anderson, 2006, 2011·bib_Lozhkin_and_Anderson_2011'bib_Lozhkin_and_

Anderson_2006). For northern Chukotka, studies covering these intervals have, until now, been limited exclusively to the lake El'gygytgyn meteorite crater record (Asikainen et al., 2007; Lozhkin et al., 2007; Melles et al., 2012, 2007 and references therein). Despite its regional significance, low accumulation rates have meant that high-resolution studies of late Quaternary palaeoenvironmental change are largely devoid. Further, the paucity of Chukotkan palaeoenvironmental records has been exacerbated by the unreliability of age-depth models due to dating limitations of lacustrine and non-lacustrine records, particularly during glacial episodes (Colman et al., 1996; Lozhkin et al., 2016). Most previous regional palaeoenvironmental reconstructions are predominantly based on palynological records of vegetation change derived from lacustrine and non-lacustrine settings (Anderson and Lozhkin, 2015; Andreev et al., 2012; Lozhkin et al., 2007; Lozhkin and Anderson, 2011). In contrast, geochemical and sedimentological datasets from lake sediments in Chukotka are vastly underrepresented (Asikainen et al., 2007). Where they exist, such studies have principally focussed on the impact of regional climate variability without considering the interaction of specific local catchment processes that are increasingly being shown to impact strongly sediment-geochemical processes (Opitz et al., 2012). Recent research from Tibetan and Himalayan lacustrine systems have highlighted the significance of catchment fluvial, aeolian and glacial-periglacial processes and the effect of lake-level changes on lacustrine development (Lehmkuhl and Haselein, 2000; Opitz et al., 2012; Wünnemann et al., 2008).

Geochemical and sedimentological proxies derived from lacustrine sediments can provide a useful record of climate-driven palaeoenvironmental change (Smol, 1988). The advent of highresolution non-destructive geochemical approaches including Xray fluorescence (XRF) analysis has allowed the detailed study of lake system responses to environmental change through the dependency of sediment-geochemistry on factors such as catchment weathering, source rock composition, sedimentation and postdepositional processes (Croudace et al., 2006; Kylander et al., 2011). The sub-centimetre down-core resolution achievable by XRF allows the capture of even short time-scale fluctuations at much higher resolutions beyond that generally achievable for other palaeoenvironmental proxies (Croudace and Rothwell, 2015). Moreover, standard sedimentological analyses including grain-size, sediment organic content and mineralogy can garner significant additional information related to clastic input, organic productivity, weathering and lake-level change that supports geochemical data and aid palaeoenvironmental interpretations (Chen et al., 2004; Opitz et al., 2012). Correlations found between certain highresolution XRF-derived elemental data and sedimentological proxies implies that XRF-geochemical data can reliably be used to represent sedimentological proxies (Biskaborn et al., 2013; Croudace and Rothwell, 2015).

Here, we present high-resolution XRF-based geochemical and sedimentological analyses of sediments from Lake Ilirney, Far East Russia. The chief objective of this study is to investigate the palaeoenvironmental development at Ilirney in response to regional climate variability since MIS4. Our interpretations are aided by acoustic sub-bottom profiling data and preliminary bioproxy data (diatoms and pollen). The hypotheses tested within this study are: a) XRF-derived geochemical variables can be used as reliable proxies for changes in organic productivity, grain-size and mineralogy. b) Lake Ilirney responds primarily to changes in lake catchment processes that reflect regional paleoenvironmental change in Chukotka during the Late Quaternary.

\section{Regional setting}

Lake Ilirney $\left(67^{\circ} 21^{\prime} \mathrm{N}, 168^{\circ} 19^{\prime} \mathrm{E}\right)$ is situated in the region of Chukotka, far east Russia at the tundra-taiga ecotone boundary within the zone of continuous permafrost (Fig. 1a,b,c). The lake is bounded by the Anadyr Mountains to the north, with elevations reaching 1790 m.a.s.l. The lake water level sits at an elevation of 407 m.a.s.l. The El'gygytgyn meteorite crater is located $160 \mathrm{~km}$ further to the east. The geology of the Anadyr mountains here comprises predominantly silicic igneous rocks of the Cretaceous Okhotsk-Chukotka Volcanic Belt composed of feldspar-rich granodiorites, rhyolite, trachyte and minor sedimentary lithologies (Ispolatov et al., 2004). Mica-rich phyllites and Quaternary glacial deposits occur on slopes surrounding Ilirney (Zhuravlev and Kazymin, 1999). Terminal moraines are identified within the lake catchment to the north-east, the largest of which retains a lake of comparable size to Ilirney (Fig. 1a). Moraine-like deposits are also found on the southern and southwestern margins of the lake. Numerous small ponds punctuate the moraines and are observed within the lake inflow region. The Ilirney basin itself is $12 \mathrm{~km}$ in length and $3.6 \mathrm{~km}$ across at its widest point and oriented north-east to south-west along a large structural feature. The basin can be split into two sub-basins: a larger depocenter in the south-west and a smaller basin in the north-east divided by a roughly north-south oriented bathymetric high (Figs. $1 \mathrm{~b}$ and $2 \mathrm{a}$ ). The maximum water depth in the southwestern basin and in the northeastern basin is 44 and $25 \mathrm{~m}$, respectively (Fig. 1b). The catchment area is $1214 \mathrm{~km}^{2}$ as calculated from a digital elevation model (ArcticDEM) (Morin et al., 2016). Ilirney is a through-flow lake with the hydrologic balance controlled by two fluvial inflows from the north-east and an outflow in the south-west. A strongly continental climate characterises Ilirney with a mean annual temperature of $-13.5^{\circ} \mathrm{C}$ and average January and July temperatures of $-33.4^{\circ} \mathrm{C}$ and $12.1^{\circ} \mathrm{C}$, respectively. Regional snowfall is equivalent to $110 \mathrm{~mm}$ of water and June-September precipitation totals $70 \mathrm{~mm}$ (Andreev et al., 2012; Nolan and Brigham-Grette, 2007). Ice cover is observed from late October to early July with snowmelt occurring in May and ice breakup by early July.

\section{Materials and methods}

\subsection{Fieldwork and acoustic profiling}

Sediment core EN18208 was obtained from Lake Ilirney during the Chukotka 2018 expedition by the Alfred Wegener Institute Helmholtz Centre for Polar and Marine research (AWI) and the Northeastern Federal University of Yakutsk (NEFU) (Kruse et al., 2019). The core was obtained from the south-western sub-basin at a water depth of $19 \mathrm{~m}$ using a UWITEC piston corer. An optimal drilling location was identified before coring using an Innomar SES2000 compact parametric sub-bottom profiler (Wunderlich and Müller, 2003). Frequency settings used were $8-10 \mathrm{kHz}$ for low frequency pulses and $100 \mathrm{kHz}$ for high frequency pulses with a pulse width of $2 \mathrm{~s}$ for low frequency and $253 \mu$ s for high frequency 


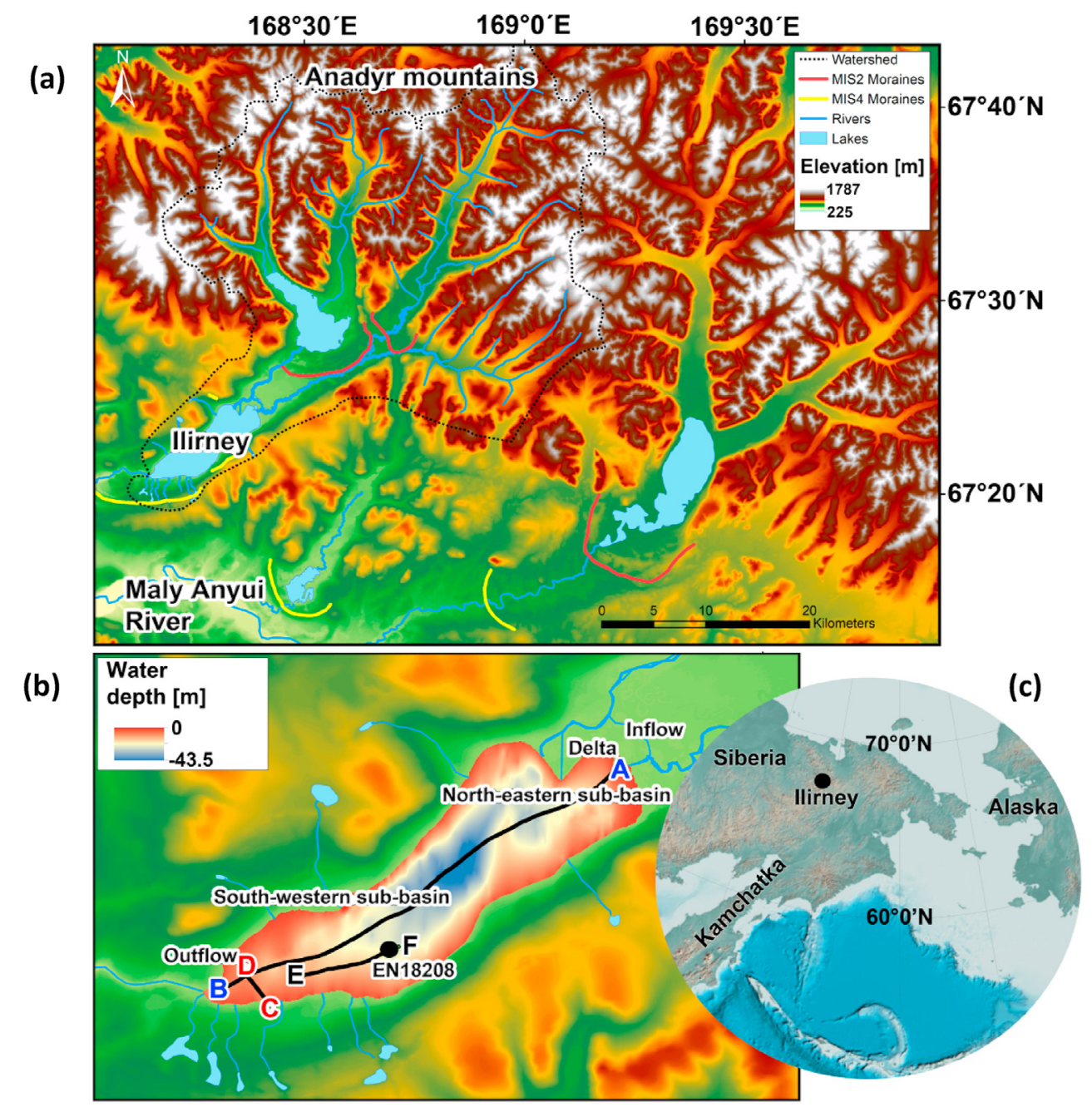

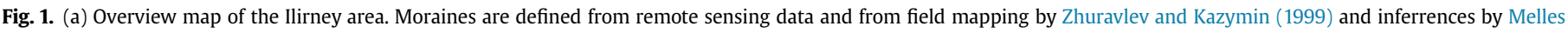

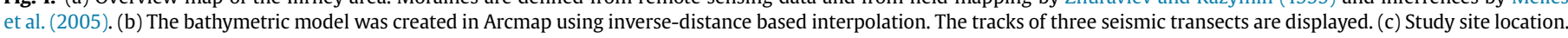

pulses. A range of $45 \mathrm{~m}$ was chosen and was altered during profiling to account for water depth variations. Sixteen acoustic profiles containing 34483 bathymetric measurements were recorded. Acoustic data were analysed using ISE2 post-processing software (Wunderlich and Müller, 2003). Bathymetric information was extracted from high-frequency data (Fig. 1b) whereas acoustic stratigraphy was retrieved from the low-frequency channel. For signal processing, the algorithm "Algo $1 \mathrm{P}^{\text {" }}$ was used alongside an optimised noise reducing algorithm. Acoustic profiles were variably stacked depending on profile length. Five acoustic units (AU5-AU1) were defined. Surface-sediment samples $(0-0.5 \mathrm{~cm})$ were obtained from multiple locations using a hydrobios sediment grabber. Water samples were collected from surface locations and analysed in situ for oxygen, pH and conductivity using a WTW Multilab 540. Subsamples were taken for anion, cation and isotopic analysis in the field (Supplement, text S1 \& Table 1). Water temperature-depth profiles were obtained for two locations in both sub-basins (Supplement, Fig. 1).

\subsection{Laboratory analyses}

\subsubsection{Core lithology}

Core lithology was evaluated following core opening at AWI
Potsdam. Splicing of overlapping core sections was carried out using high-resolution XRF data and visual inspection. The composite $10.76 \mathrm{~m}$ core comprises laminated and non-laminated lacustrine silt and clay over a basal sand layer. From the sediment surface to $196 \mathrm{~cm}$ core depth laminated, grey-brown coloured silt dominates succeeded by non-laminated, grey clayey silt between 196 and $650 \mathrm{~cm}$ core depth. The lithology between 650 and $900 \mathrm{~cm}$ comprises grey-brown fine-silt with the reoccurrence of laminations and a thin sand layer at $884 \mathrm{~cm}$. Grey clayey silt dominates from $900 \mathrm{~cm}$ to $1055.5 \mathrm{~cm}$. From $1055.5 \mathrm{~cm}$ to the end of the core at $1076 \mathrm{~cm}$ is a basal sand with clasts preventing further core retrieval. From $900 \mathrm{~cm}$ to $1055.5 \mathrm{~cm}$ grey clayey silt reappears. From $1055.5 \mathrm{~cm}$ to the core end is a basal sand with large grains preventing further core retrieval. No macrofossils or plant remains were observed in the entire core. Vivianite $\left(\mathrm{Fe}_{3}\left(\mathrm{PO}_{4}\right)_{2} \cdot 8 \mathrm{H}_{2} \mathrm{O}\right)$ was identified by visual inspection and has an irregular distribution with core depth. Laminations were principally black in colouration following core opening but were occasionally orange-brown. Laminations were irregularly spaced and thickness varied on a subcentimetre scale.

\subsubsection{Dating}

Due to the lack of observed macrofossils for radiocarbon $\left({ }^{14} \mathrm{C}\right)$ 


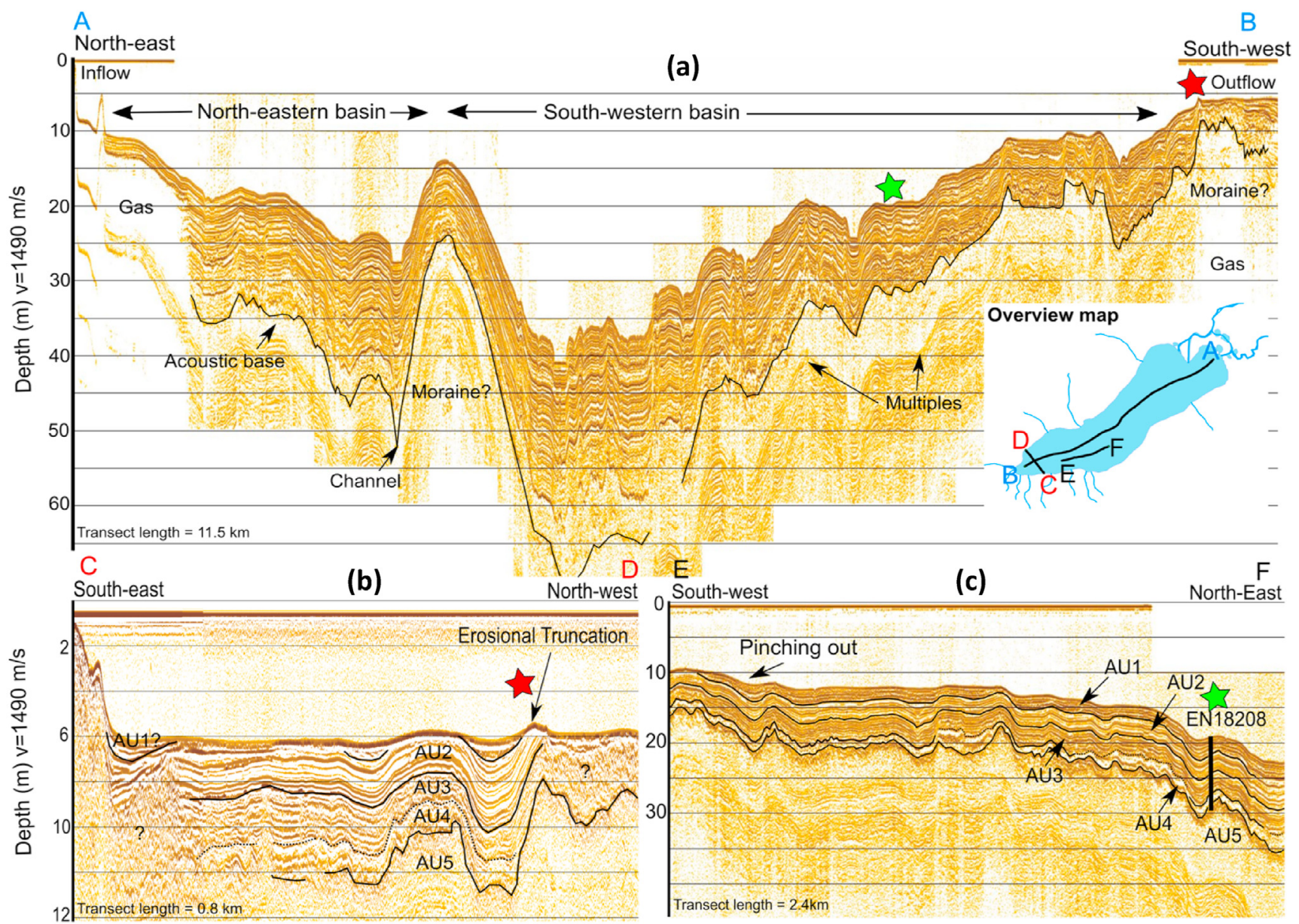

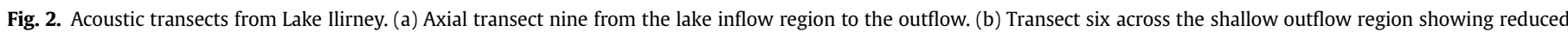

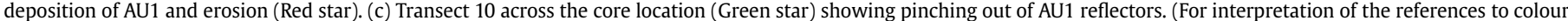
in this figure legend, the reader is referred to the Web version of this article.)

dating, a high-resolution approach was used with 25 bulk sediment TOC samples being dated using accelerator mass spectrometry (AMS) at the MICADAS radiocarbon laboratory, Bremerhaven, Germany (Table 1). Samples were prepared following the standard MICADAS preparation procedure. (Supplement, text 2) (Grotheer et al., 2020; Synal et al., 2007; Wacker et al., 2010). One surface sample was dated to constrain any "old carbon" effect present. ${ }^{14} \mathrm{C}$ dates were calibrated using the IntCal13 calibration curve (Reimer et al., 2013). Seven optically stimulated luminescence (OSL) samples were dated at the Royal Holloway Luminescence Laboratory. OSL dating was performed on 4-11 $\mu \mathrm{m}$ quartz mounted on aluminium discs (Table 2) using a Risø TL/OSL-DA-15 automated dating system (Bøtter-Jensen et al., 2003) following the singlealiquot regenerative-dose procedure (Murray and Wintle, 2000). Alpha, beta and gamma dose rates were calculated using the conversion factors of Guérin et al. (2011) from U, Th and K concentrations determined via a combination of thick-source alpha counting (Daybreak Nuclear and Medical Systems Model 583) and beta counting (Risø Model GM-25-5 A). Cosmic dose rates were calculated using latitude, longitude, elevation and modern overburden (Prescott and Hutton, 1988)(Supplement, text 2). OSL dates in calendar years are corrected to calendar years before present (BP) by subtraction of 69 years (Table 2). An age model, incorporating radiocarbon and OSL dates was created in the MATLAB software "Undatable" (Lougheed and Obrochta, 2019). All modelled ages are presented as mean calendar years BP (ka BP) for consistency with modelled uncertainty represented as $\pm 1 / 2$ of the 1 sigma range.

\subsubsection{X-ray fluorescence analysis (XRF)}

High-resolution, semi-quantitative sediment geochemical data were obtained by X-ray fluorescence line-scanning (XRF) of EN18208 archive halves. XRF was carried out using an AVAATECH XRF-scanner with a Rh X-ray tube at $0.75 \mathrm{~mA}$ and $1.5 \mathrm{~mA}$ for 10 and $15 \mathrm{~s}$, at $10 \mathrm{kV}$ (no-filter) and $30 \mathrm{kV}$ (Pd-thick filter) at the Bundesanstalt für Geowissenschaften und Rohstoffe (BGR), Germany. A scanning resolution of $5 \mathrm{~mm}$ was chosen. Before scanning, the sediment surface was levelled and cleaned. A $4 \mu \mathrm{m}$ ultralene foil was placed over the cleaned surface. The main rock-forming elements (Aluminium (Al), Silicon (Si), Calcium (Ca), Potassium (K), Titanium (Ti), Rubidium (Rb), Strontium (Sr), Zircon (Zr)) and redox/productivity linked elements (Manganese $(\mathrm{Mn})$, Iron (Fe), Bromine (Br)) were selected based on low element $\mathrm{Chi}^{2}$ values ( $\mathrm{Al}$ 1.1, Si 3, Ca 2.8, K 6.6, Ti 1, Rb 0.9, Sr 0.8, Zr 0.7, Mn 0.6, Fe 3.2, Br 2.8). Commonly used element ratios ( $\mathrm{Mn} / \mathrm{Fe}, \mathrm{Zr} / \mathrm{Rb}, \mathrm{K} / \mathrm{Ti}, \mathrm{Si} / \mathrm{Al}$ ) were constructed from element intensities (Croudace and Rothwell, 2015). Raw element intensities (CPS) were centre-log ratio (CLR) transformed and element ratios were additive log ratio (ALR) transformed to reduce closure effects (Aitchison, 1984; Weltje and Tjallingii, 2008). Due to the inherent heterogeneity of the sediment (e.g. grain-size effects) and to reduce the potential effects of outliers within the XRF data, a 10-point running mean was applied to the 
Table 1

Lake Ilirney ${ }^{14} \mathrm{C}$ dates. All samples analysed as bulk total organic carbon (TOC). Samples marked with ${ }^{\mathrm{a}}$ are not included in the age model calculation (section 4.2 ).

\begin{tabular}{|c|c|c|c|c|c|}
\hline Sample ID & Lab ID & Composite depth $(\mathrm{cm})$ & $\begin{array}{l}{ }^{14} \mathrm{C} \text { date }(\mathrm{a} B P) \text { and } \\
\text { Uncertainity }(\mathrm{a})\end{array}$ & $\begin{array}{l}\text { "Old carbon" corrected and } \\
\text { calibrated age ( } 95 \% \text { confidence interval) (cal. a BP) }\end{array}$ & Method \\
\hline EN18214 0-0.5 & 3754.1 .1 & 0.25 & $1721 \pm 28$ & - & Bulk TOC \\
\hline EN18208-3 20-21 & 2974.1 .1 & 16 & $4029 \pm 26$ & $2208-2357$ & Bulk TOC \\
\hline EN18208-3 40-41 & 2975.1 .1 & 36 & $5664 \pm 27$ & $4292-4513$ & Bulk TOC \\
\hline EN18208-3 60-61 & 2976.1 .1 & 56 & $7334 \pm 28$ & $6313-6445$ & Bulk TOC \\
\hline EN18208-3 80-81 & 2977.1.1 & 76 & $8279 \pm 28$ & $7426-7552$ & Bulk TOC \\
\hline EN18208-3108-109 & 2978.1.1 & 104 & $10579 \pm 30$ & $9785-10157$ & Bulk TOC \\
\hline EN18208-3128-129 & 2979.1 .1 & 124 & $11738 \pm 31$ & $11327-11702$ & Bulk TOC \\
\hline EN18208-3148-149 & 2980.1 .2 & 144 & $12914 \pm 32$ & $13004-13120$ & Bulk TOC \\
\hline EN18208-3168-169 & 2981.1.1 & 164 & $13586 \pm 33$ & $13576-13760$ & Bulk TOC \\
\hline EN18208-3188-189 & 2982.1 .2 & 184 & $16099 \pm 40$ & $17342-17682$ & Bulk TOC \\
\hline EN18208-3214-215 & 2983.1 .2 & 210 & $19953 \pm 80$ & $21864-22331$ & Bulk TOC \\
\hline EN18208-3250-251 & 2984.1 .2 & 246 & $23685 \pm 105$ & $25942-26458$ & Bulk TOC \\
\hline EN18208-4 45-46 & 2985.1 .2 & 282.5 & $25695 \pm 134$ & $27738-28361$ & Bulk TOC \\
\hline EN18208-4 88-89 & $2986.1 .3^{a}$ & 325.5 & $23488 \pm 65$ & $25852-26136$ & Bulk TOC \\
\hline EN18208-4140-141 & $2987.1 .2^{\mathrm{a}}$ & 377.5 & $30941 \pm 244$ & $32867-33885$ & Bulk TOC \\
\hline EN18208-4170-171 & $2988.1 .2^{\mathrm{a}}$ & 407.5 & $29612 \pm 95$ & $31322-31886$ & Bulk TOC \\
\hline EN18208-4220-221 & $2989.1 .2^{\mathrm{a}}$ & 457.5 & $32700 \pm 294$ & $34348-35532$ & Bulk TOC \\
\hline EN18208-4257-258 & $2990.1 .1^{a}$ & 494.5 & $33068 \pm 121$ & $34877-35569$ & Bulk TOC \\
\hline EN18208-5 46-47 & $2991.1 .1^{\mathrm{a}}$ & 561 & $26314 \pm 67$ & $28421-28823$ & Bulk TOC \\
\hline EN18208-5151-152 & $2992.1 .2^{\mathrm{a}}$ & 666 & $25595 \pm 64$ & $27717-28086$ & Bulk TOC \\
\hline EN18208-5240-241 & 2993.1 .3 & 755 & $29670 \pm 102$ & $31345-32004$ & Bulk TOC \\
\hline EN18208-6 40-41 & 2994.1.1 & 797 & $29040 \pm 84$ & $31039-31374$ & Bulk TOC \\
\hline EN18208-6 75-76 & 2995.1 .2 & 832 & $30109 \pm 94$ & $31807-32768$ & Bulk TOC \\
\hline EN18208-6110-111 & 2996.1 .2 & 867 & $30540 \pm 228$ & $32238-33614$ & Bulk TOC \\
\hline
\end{tabular}

Table 2

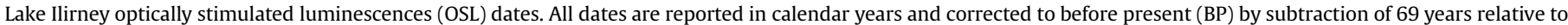
the measurement date. Samples marked with ${ }^{\mathrm{a}}$ are not included in the age model calculation (section 4.2).

\begin{tabular}{|c|c|c|c|c|c|}
\hline Sample ID & Lab ID & Composite depth $(\mathrm{cm})$ & OSL date (a) and Uncertainty (a) & BP corrected OSL date (a BP) & Method \\
\hline VY163 & VY163 & 165.5 & $15000 \pm 1300$ & 14931 & OSL \\
\hline VY373 & VY373 ${ }^{\mathrm{a}}$ & 375.5 & $17900 \pm 1700$ & 17831 & OSL \\
\hline VY473 & VY473 ${ }^{\mathrm{a}}$ & 475.5 & $22700 \pm 2300$ & 22631 & OSL \\
\hline VY663 & VY663 ${ }^{\mathrm{a}}$ & 666 & $25800 \pm 2500$ & 25731 & OSL \\
\hline VY882 & VY882 & 884.5 & $35600 \pm 3200$ & 35531 & OSL \\
\hline VY963 & VY963 & 966 & $37800 \pm 3300$ & 37731 & OSL \\
\hline VY1063 & VY1063 & 1066 & $53400 \pm 4800$ & 53331 & OSL \\
\hline
\end{tabular}

geochemical datasets and used in multivariate statistical analyses (Löwemark et al., 2011).

\subsection{4. $X$-ray diffractometry (XRD) and scanning electron microscopy (SEM)}

Core bulk mineralogy was derived by XRD analyses of 54 freezedried and milled samples. Samples were analysed using a PW1820 goniometer (PHILIPS, Netherlands) $\left(40 \mathrm{kV}, 40 \mathrm{~mA}\right.$, from 3 to $100^{\circ}$, step-rate $0.05^{\circ}$, Co k $\alpha$ radiation) at AWI Bremerhaven. MacDiff 4.2.6 software was used to analyse the data (Petschick, 2002). Peak intensities of the main minerals (Quartz peak $3.34 \AA$ A, Plagioclase feldspar peak $3.19 \AA$ And K-feldspar peak $3.24 \AA$ ) were expressed as ratios of the total sum of main mineral intensities (TI) to reduce the impact of organic material and diatom derived opal (Biskaborn et al., 2013). XRD was supported by scanning electron microscopy/energy dispersive X-ray spectroscopy (SEM-EDS) analysis of 5 samples at the GFZ Potsdam using a FEI Quanta 3D Dual Beam microscope.

\subsubsection{Sediment biogeochemical, diatom and pollen analyses}

Water content and bulk density of 125 sediment samples was derived using a volumetric approach (Avnimelech et al., 2001). Subsequently, dried and milled samples were analysed for total carbon (TC), total nitrogen (TN) and total organic carbon (TOC). TN and TC were measured using a Vario EL III carbon-nitrogen-sulphur analyser. TOC content was determined using a Vario MAX C analyser. The TOC/TN ratio was calculated from TOC and TN (Meyers and Teranes, 2005). Low TOC and N contents at some depths were at, or close to the detection limit but were still used for calculation of TOC/TN ratios and in statistical analyses. Twenty smear slide samples were prepared and analysed for percentage coverage of diatoms relative to other biogenic and lithogenic grains (Terry and Chilingar, 1955). An additional 15 samples were taken from depths identified to contain diatoms and prepared for diatom analysis following the standard procedure (Battarbee et al., 2001). Diatom slides were prepared on a hot plate using Naphrax mounting medium. A minimum of 300 (and up to 400) diatom valves were counted in each sample using a Zeiss AXIO Scope.A1 light microscope with a Plan-Apochromat $100 \times / 1.4$ Oil Ph3 objective at $1000 \times$ magnification for the calculation of the benthic/ planktonic ratio (Stevens et al., 2006; Wang et al., 2011). Forty three pollen samples were prepared with adding one tablet of Lycopodium spores (batch-number: 3862, spores: 20848) to each pollen sample after sample weighing for pollen concentrations (Stockmarr, 1971). At least 300 pollen grains were counted per sample at 400x magnification.

\subsubsection{Grain-size analysis}

54 original samples were treated with hydrogen peroxide $\left(\mathrm{H}_{2} \mathrm{O}_{2}\right)$ for five weeks to remove organic matter. Samples were then homogenised using an elution shaker for $24 \mathrm{~h}$ and split into eight subsamples. At least three subsamples were analysed providing 
nine individual measurements using a Malvern Mastersizer 3000 laser diffraction particle analyser. Five additional surface sediment samples were collected from different depositional settings (River channel, channel pond, river delta, lacustrine, shore; Supplement Fig. 2). Intervals of $2 \mathrm{~mm}-63 \mu \mathrm{m}, 63$ to $2 \mu \mathrm{m}$ and finer than $2 \mu \mathrm{m}$, were used to define the percentages of sand, silt and clay, respectively. The geometric method of moments mean grain size was retrieved using GRADISTAT software (Blott and Pye, 2001).

\subsubsection{Statistics}

To identify intercorrelated sediment geochemical and sedimentological variables, Pearson correlation analysis was performed on selected variables using the Corrplot package (Wei and Simko, 2017) within the R environment (R Core Team, 2019). Only correlations with $p$-values less than 0.001 are coloured within the resulting correlation matrix to reduce the false discovery rate to below 5\% (Biskaborn et al., 2019; Colquhoun, 2014) (Appendix Fig. 1). Lithological units (LUs) were defined using stratigraphically constrained incremental sum of squares cluster analysis (CONISS) applied to high-resolution XRF data after computation of the dissimilarity matrix and aided by visual identification of major sedimentological boundaries (Grimm, 1987). Six major LUs (I-VI) are identified. LUII is subdivided into three subunits due to small scale variations (IIa,b,c). LUs were correlated with acoustic units delineated from acoustic transects taken at the core location. In order to investigate the principal variations in geochemical and sedimentological data amongst lithological units, principal component analyses (PCA) were run on normalised and centred data using prcomp in R. PCA biplots were plotted with $68 \%$ probability ellipsoids for each identified cluster. In order to provide some measure of uncertainty regarding obtained proxies, $95 \%$ confidence intervals were calculated for grain-size, sediment biogeochemical and mineralogical datasets. Two coarse basal-sand samples were excluded from statistical analyses due to extreme values relative to overlying fine-grained limnic sediment.

\section{Results}

\subsection{Acoustic stratigraphy}

Sediment infill was imaged to acoustic basement within all

(a)

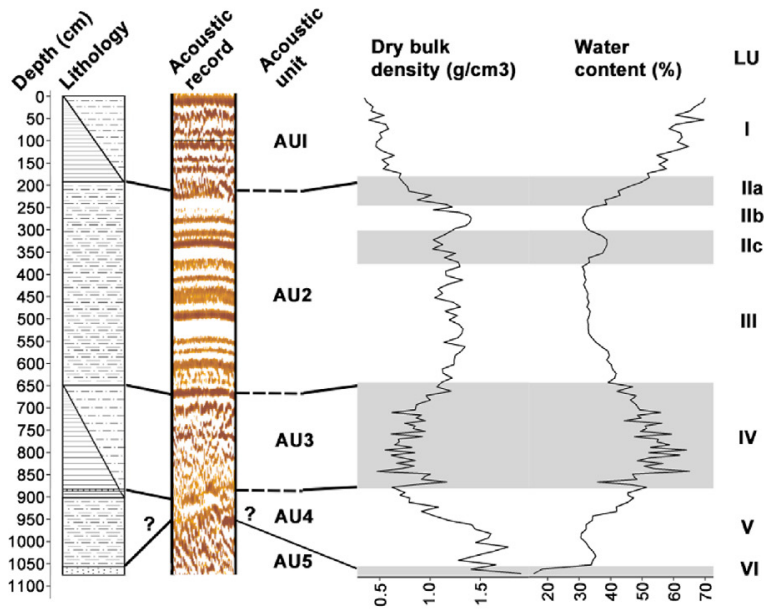

acoustic profiles (Fig. 2a-c). Sediments are well-stratified with strong reflectors and observed to drape over bathymetric structures allowing many reflectors to be traced throughout the basin. Acoustic transect nine follows the lake axis $(\mathrm{A}-\mathrm{B})$ and provides a profile of whole basin stratigraphy (Fig. 2a). Acoustic transect six (C-D) includes stratigraphy within the shallow outflow region. Acoustic transect 10 passes the core location $(\mathrm{E}-\mathrm{F})$ and is used alongside physicochemical variables to delineate acoustic units (AU5-AU1) (Fig. 3a) (Supplement table 3).

AU5 represents the bottommost acoustic unit and includes the basal sand synonymous with LUVI. A lower boundary to AU5 is not observed but a discontinuous upper boundary of variable amplitude and undulating topography is seen. Evidence of channels are seen within AU5 that affect the subsequent depositional pattern (Fig. 2a, Supplement Fig. 3). Large bathymetric structures within AU5 include a bathymetric high dividing the lake into northeastern and south-western sub-basins, and basement structures in the shallow outflow region. AU4, representing LUV, comprises continuous-discontinuous sub-horizontal reflectors occasionally seen to onlap onto AU5 (Fig. 2c). AU4 is present throughout and is thickest within the south-western basin. AU3 represents LUIV and corresponds with higher water content and lower bulk density with reflectors of variable amplitude. AU2 consists of strong amplitude, continuous sub-horizontal reflectors and includes LUIII and LUII. AU1 constitutes recent sedimentation represented by LUI and demonstrates continuous-discontinuous reflectors more variable in amplitude than those in AU2. In general, lacustrine deposits within AU4-2 are present throughout the basin. Some variability in the distribution of AU2 and AU1 is observed at shallow water depths $(<10 \mathrm{~m})$ manifested by thinning and pinching out of reflectors of AU1 onto AU2 (Fig. 2c). Evidence of erosional truncation of AU2 is apparent in the outflow region with thinner deposits relating to AU1 deposited unconformably on top (Fig. 2b). The thickness of the sediment package is variable reaching $30 \mathrm{~m}$ in the deepest regions of the south-western basin but reduces to $<10 \mathrm{~m}$ with distance from the lake inflows and towards the outflow (Fig. 2a).

\subsection{Age-depth model}

An "old carbon" reservoir effect of $1721 \pm 28{ }^{14} \mathrm{C}$ yr BP was

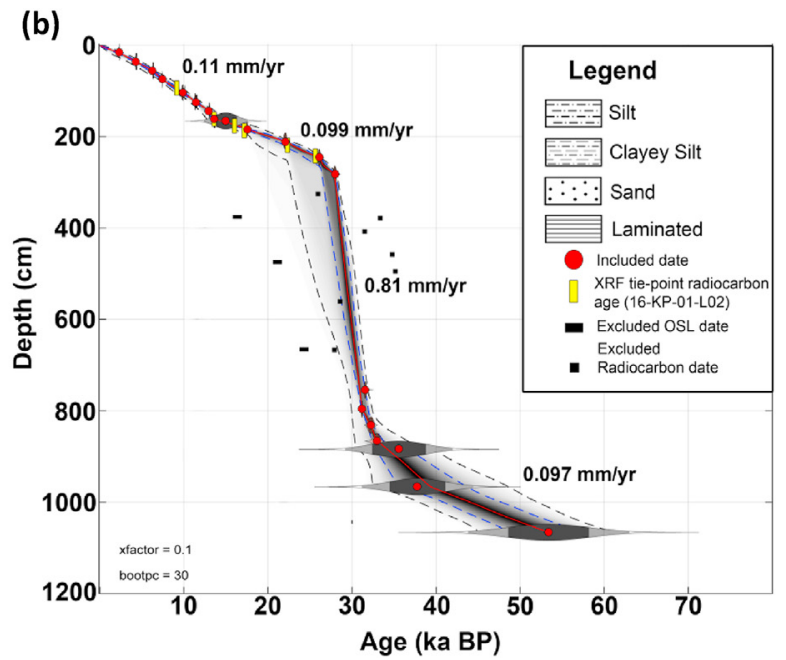

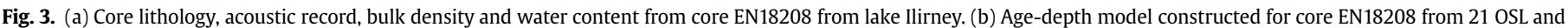

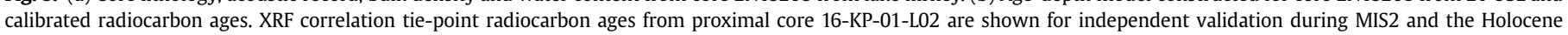
(Andreev et al., unpublished data). 
determined from dated surface sediments $(0-0.5 \mathrm{~cm})$. We assume this effect remained constant through time, and thus subtracted this age from down-core radiocarbon dates before calibration. Reservoir corrected and Intcal13 calibrated ages together with OSL show a maximum age of $53.4( \pm 4.5)$ ka BP within the basal sand. The resulting age-depth model was based on four OSL and 17 radiocarbon dates (Fig. 3b). A high agreement between ${ }^{14} \mathrm{C}$ dates and an OSL date at $165.5 \mathrm{~cm}$ validate an effective model for the Holocene and late glacial. Moreover, the close fit between ${ }^{14} \mathrm{C}$ and OSL dates from $755 \mathrm{~cm}$ to the core base support an effective model for the lowermost core. ${ }^{14} \mathrm{C}$ measurements between 282 and $755 \mathrm{~cm}$ returned older ages than OSL dates particularly between 375 and $494.5 \mathrm{~cm}$. This disparity may be partially attributed to the redeposition of "old carbon" from the catchment (Gromig et al., 2019). The low organic content of the lake sediment (sect. 4.3.1) and lack of macrofossils available for dating may also contribute to this (Lozhkin et al., 2016; Müller et al., 2010). Using the same measurement technique as applied in this study, OSL samples from El'gygytgyn also yielded large age underestimates attributed to saturation effects (Zander and Hilgers, 2013). Although the expected absorbed doses were very large (>200 Gy) and age underestimates increased with depth.

Additional support for our age model during MIS2 is garnered from XRF-based correlation with ${ }^{14} \mathrm{C}$ dated palynological record from Ilirney (16-KP-01-L02) (Andreev et al., unpublished data)(Fig. 3b). The similarity of our age-model to that of a similar age glacial lake within the Verkhoyansk mountains of Yakutia provides additional support from $50 \mathrm{ka}$ BP to the present (Diekmann et al., 2016). To negate radiocarbon and OSL date differences, dates between 282 and $755 \mathrm{~cm}$ were not included in the age-depth model calculations. Based on the age model, the mean temporal resolution between samples for sediment biogeochemical analyses is $422 \mathrm{yrs}$. Sedimentation rates were highest within LUIV and LUIII $\left(0.81 \mathrm{yr}^{-1}\right)$ and within LUI $\left(0.11 \mathrm{yr}^{-1}\right)$. LUV and LUII had the lowest sedimentation rates of 0.097 and $0.099 \mathrm{yr}^{-1}$, respectively.

\subsection{Physicochemical sediment composition}

\subsubsection{Sediment biogeochemical and redox proxies}

Core EN18208 demonstrates very low values for $\mathrm{Br}$ (mean -4.8), TC (mean 0.67\%), TOC (mean 0.59\%) and TOC/TN (mean 5) at all depths reaching maximum values only within LUI (Fig. 4b). The lowest values of $\mathrm{Br}, \mathrm{TC}, \mathrm{TOC}$ and TOC/TN occur in LUVI $(1076.5-1055 \mathrm{~cm}), \mathrm{LUV}(1055-880 \mathrm{~cm})$ and within LUII particularly in LUIIc (376- $300 \mathrm{~cm})$, LUIIb $(300-244 \mathrm{~cm})$ and within the lower part of LUIIa prior to a sharp increase in values from $230 \mathrm{~cm}$ towards the LUIIa/LUI transition. Two prominent minima represented most clearly by extremely low values of TC occur within LUV at $950 \mathrm{~cm}(0.241 \%)$ and within the uppermost part of LUIIb at $247.5 \mathrm{~cm}$ (0.242\%). Moderate values of organic proxies prevail in LUIV (880$642 \mathrm{~cm}$ ) following dramatic increases in $\mathrm{Br}$ and TC prior to the LUV/ LUIV boundary and are accompanied by the appearance of laminations denoted by peaks in $\mathrm{Fe}$ and $\mathrm{Mn}$ in geochemical data. Moderate and stable TOC and TC values are observed in the lower part of LUIII ( $642-376 \mathrm{~cm}$ ) which, after a plateau between 561.5 and $501.5 \mathrm{~cm}$, decline towards the LUIII/LUII transition. $\mathrm{Br}$ values decline consistently across LUIII. Except for a small reversal in $\mathrm{Br}$ values at $128 \mathrm{~cm}$, values of all organic proxies within LUI $(178.5-0 \mathrm{~cm})$ increase steadily towards the sediment surface and Fe and Mn laminations reappear (Fig. 5) (Supplement Fig. 4). The mean time interval between laminations in LUI is $567 \mathrm{yr}$ with a range of $1412 \mathrm{yr}$.

$\mathrm{Mn} / \mathrm{Fe}$ values are generally variable within the core but are highest within LUI and the uppermost part of LUIV $(729-642 \mathrm{~cm})$.
The lowest values are found within LUV with two minima at $1051 \mathrm{~cm}(-4.20)$ and $910 \mathrm{~cm}$ (- 4.19). Persistently low values predominate most of LUIV until $729 \mathrm{~cm}$. Low values occur throughout LUII but particularly in LUIIc and at the LUIII/LUII transition. LUIII demonstrates moderate values that decline towards the LUIII/LUII transition. In LUI, Mn/Fe values increase towards the sediment surface but are interrupted by a reversal synchronously with $\mathrm{Br}$ at $128 \mathrm{~cm}$.

\subsubsection{Grain-size and mineralogical proxies}

SEM-EDS analysis shows a dominance of sediment components rich in $\mathrm{O}, \mathrm{Si}$ and $\mathrm{Al}$ with minor $\mathrm{K}, \mathrm{Na}, \mathrm{Ca}$ and Fe (Fig. 6a). Mean geometric grain-size varies between $195.5 \mu \mathrm{m}$ and $2.41 \mu \mathrm{m}$ and is highest within the basal sand of LUVI. Grain-sizes are coarser at the base of LUV and throughout LUIV and LUI. The finest grain-sizes occur within LUV and LUII and particularly within LUIIc and the lower part of LUIIa. Pronounced grain-size minima within LUV $(931.5 \mathrm{~cm})$ and LUII $(351.5 \mathrm{~cm}$ and $231.5 \mathrm{~cm})$ are coincident with clay maxima and minima in silt contents. LUIII demonstrates moderate to low grain-size values that fine towards the LUIII/LUII transition accompanying decreasing sand contents. LUIIb also shows moderate to low grain-size values marked by increased silt and decreased clay. SEM-EDS analysis of a sample from LUIIb $(253.5 \mathrm{~cm})$ shows the presence of a coarse, sub-angular, striated quartz-grain (Fig. 6a and b). Dramatic increases in grain-size occur from $911.5 \mathrm{~cm}$ to the LUV/LUIV boundary and within the upper part of LUIIa above $211.5 \mathrm{~cm}$ to the LUII/LUI transition. Variations in grain-size are tracked closely by variations in XRF ratios of $\mathrm{Zr} / \mathrm{Rb}, \mathrm{Si} /$ $\mathrm{Al}$ and $\mathrm{K} / \mathrm{Ti}$. Generally high values of $\mathrm{Zr} / \mathrm{Rb}$ and $\mathrm{Si} / \mathrm{Al}$ relate to coarser silt and sand dominated sediments and higher values of $\mathrm{K} /$ Ti with finer, clay-dominated material. XRD-derived core mineralogy shows that Feldspar/TI ratios were highest within the basal sand of LUVI and within LUV, LUII and to an extent within LUIII. Lower values were found predominantly within LUIV and LUI. XRFderived Ca varies alongside Plagioclase-feldspar/TI, whereas K/Ti ratio values can be seen to covary with K-feldspar/TI values. Quartz/ TI ratio values are overall higher within LUIV and LUI and to a lesser extent within LUIIb and the upper part of LUIII and are low within LUVI, LUV and LUIIc and LUIIa. No carbonate was found within XRD or SEM-EDS samples analysed.

\subsection{Bioproxies}

Diatom percentages and total pollen concentrations show major shifts throughout EN18208. Diatoms are absent from samples in LUV and pollen concentrations are very low $\left(<3000\right.$ grains $\left.\mathrm{g}^{-1}\right)$, reaching extremely low values between 931 and $920 \mathrm{~cm}$ (Fig. 7). Samples from LUIV show increasing pollen concentrations, attaining very high values (40000 grains $\mathrm{g}^{-1}$ ) at $782 \mathrm{~cm}$. Diatom percentages in LUIV are up to $50 \%$ with large, abundant planktonic taxa seen within SEM samples (Fig. 6c). Benthic/planktonic ratios for LUIV are low (0.13-0.003) reflecting the dominance of planktonic taxa. In the upper part of LUIV, pollen concentrations decline and the benthic/planktonic ratio remains low with almost a disappearance of diatoms close to the LUIV/LUIII transition. Pollen concentrations reduce to low values in LUIII, $\left(<5000\right.$ grains $\left.\mathrm{g}^{-1}\right)$ especially at the LUIII/LUII transition $\left(<2000\right.$ grains $\left.^{-1}\right)$ and remain low throughout LUII. Concentrations vary in LUIIc with marginal increases to around 3000 grains $\mathrm{g}^{-1}$ towards the mid-upper section. Consistent values persist throughout LUIIb before decreasing to extremely low values ( $<2000$ grains $\mathrm{g}^{-1}$ ) in LUIIa. Pollen concentrations from the uppermost part of LUIIa and LUI were not calculated in core EN18208. The pollen record from a proximal 2016 Ilirney core (16-KP-01-L02), however, provides vegetation and palaeoclimatic information (Andreev et al., unpublished data) and 
(a)

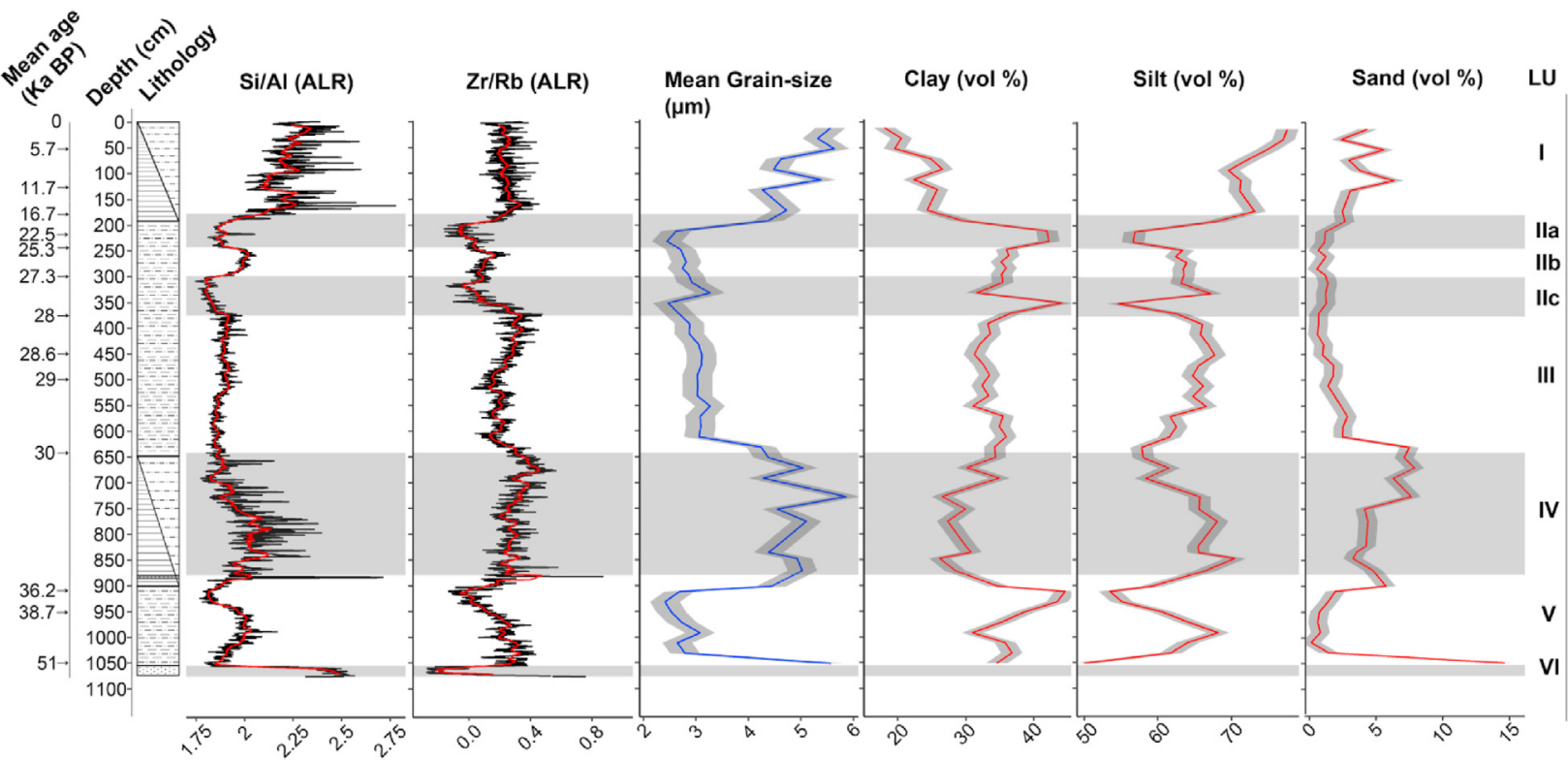

(b)

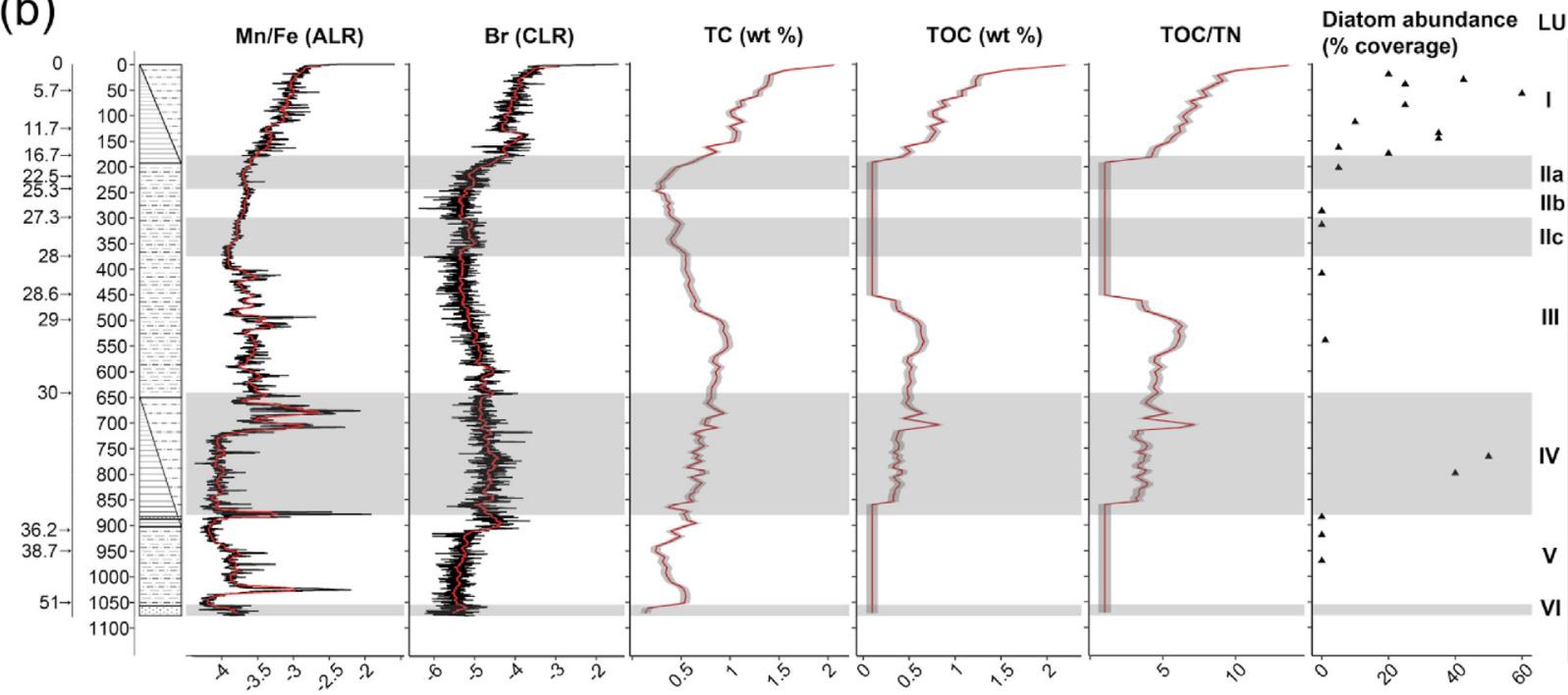

(c)

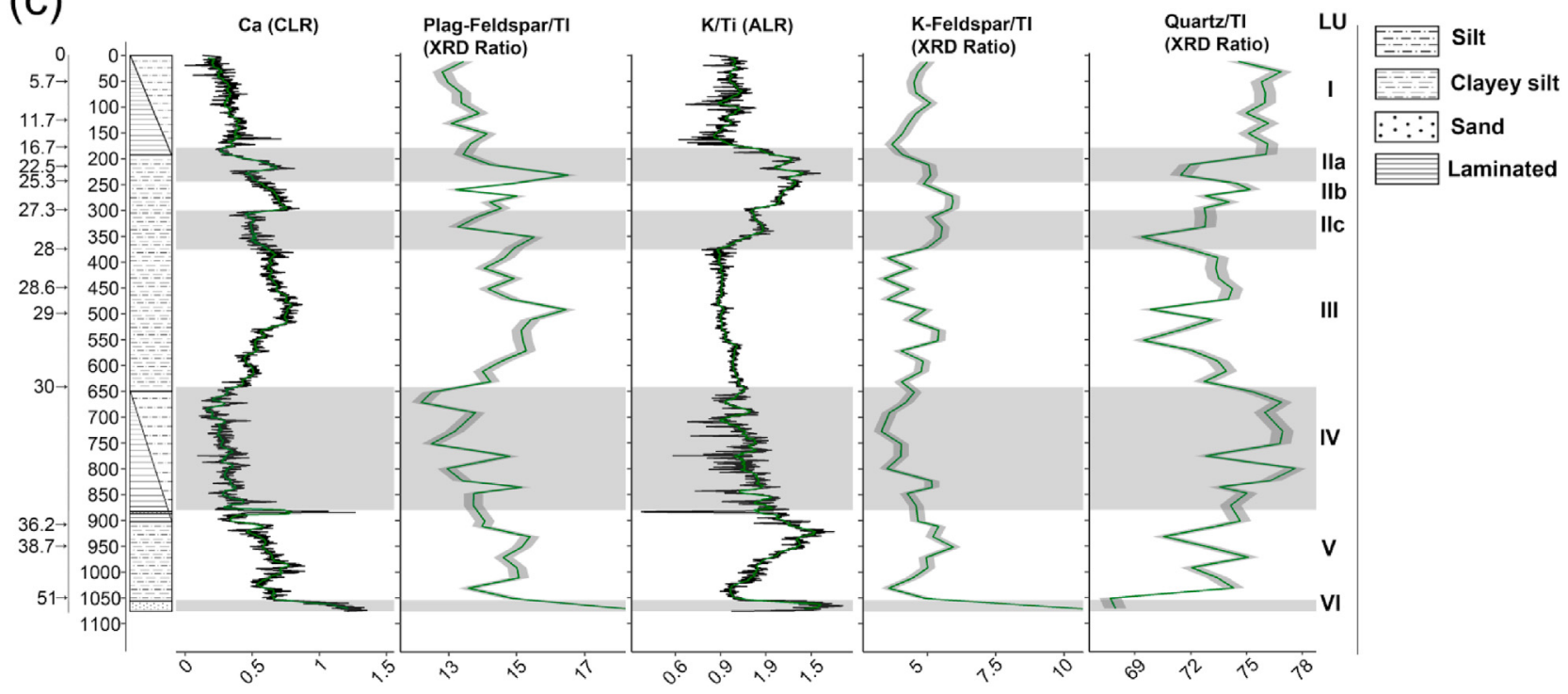

Fig. 4. Selected sediment-geochemical and sedimentological variables in core EN18208. a) Grain-size proxies b) Organic proxies along with smear slide estimated diatom percentages. c) Mineralogical proxies. ALR = additive log ratio; $C L R=$ centre-log ratio; $\mathrm{TI}=$ total sum of main mineral intensities. 95\% confidence limits are shown alongside selected sedimentological variables (grey bands). 


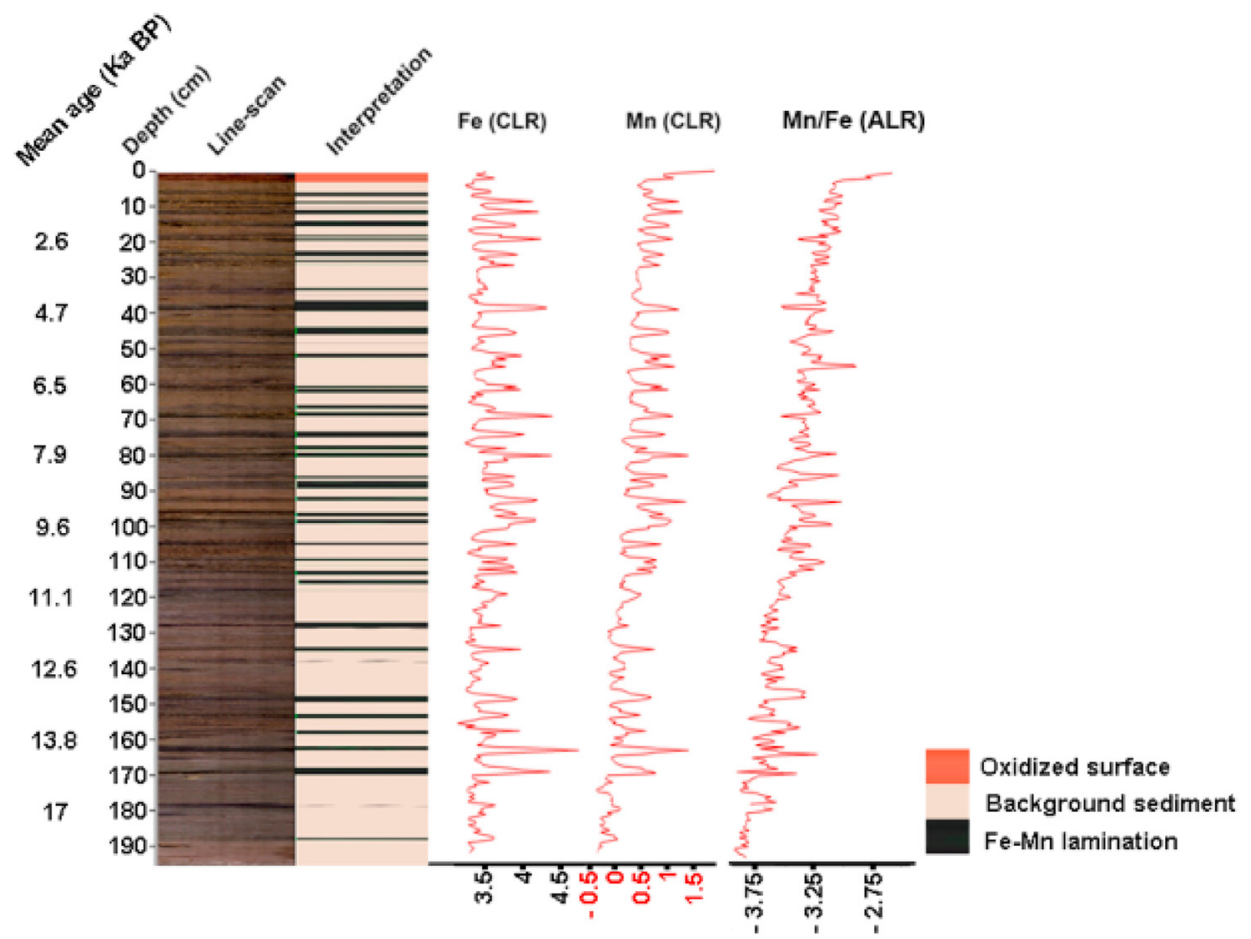

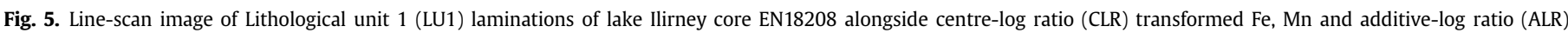
transformed $\mathrm{Mn} / \mathrm{Fe}$ XRF profiles.
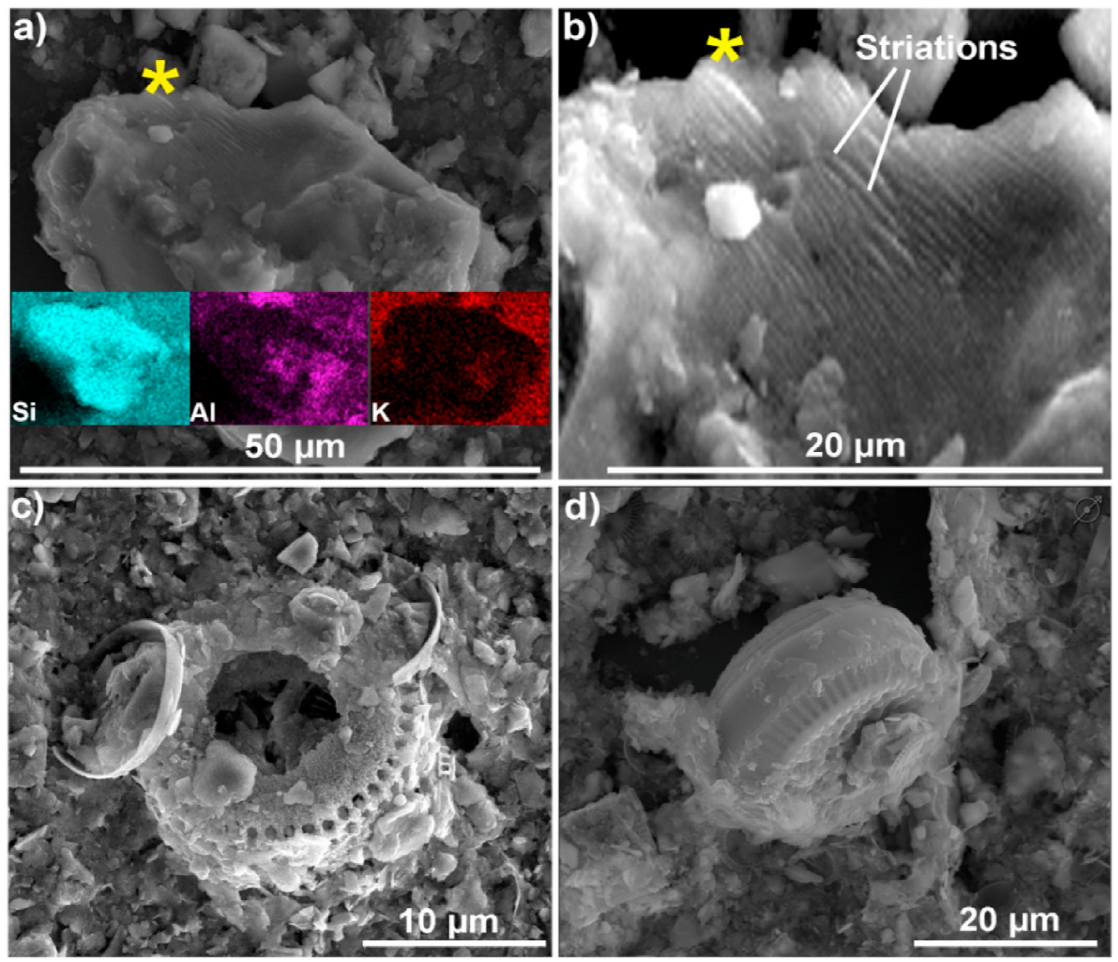

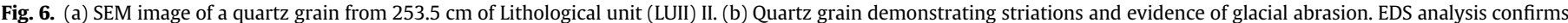
the grain as exclusively silica dominated and hence a quartz grain. (c) Planktonic diatoms preserved within LUIV. (d) Abundant diatoms were found within LUI.

is considered in the subsequent discussion. Diatoms remain absent throughout LUIIc,b and the majority of IIa and only appear again at the top of LUIIa returning to prominence within LUI with percentage abundances reaching up to $60 \%$ relative to other biogenic and lithogenic grains present within smear slides. Benthic/planktonic diatom ratios within LUI are higher than observed for LUIV with values between 0.15 and 0.43 . 


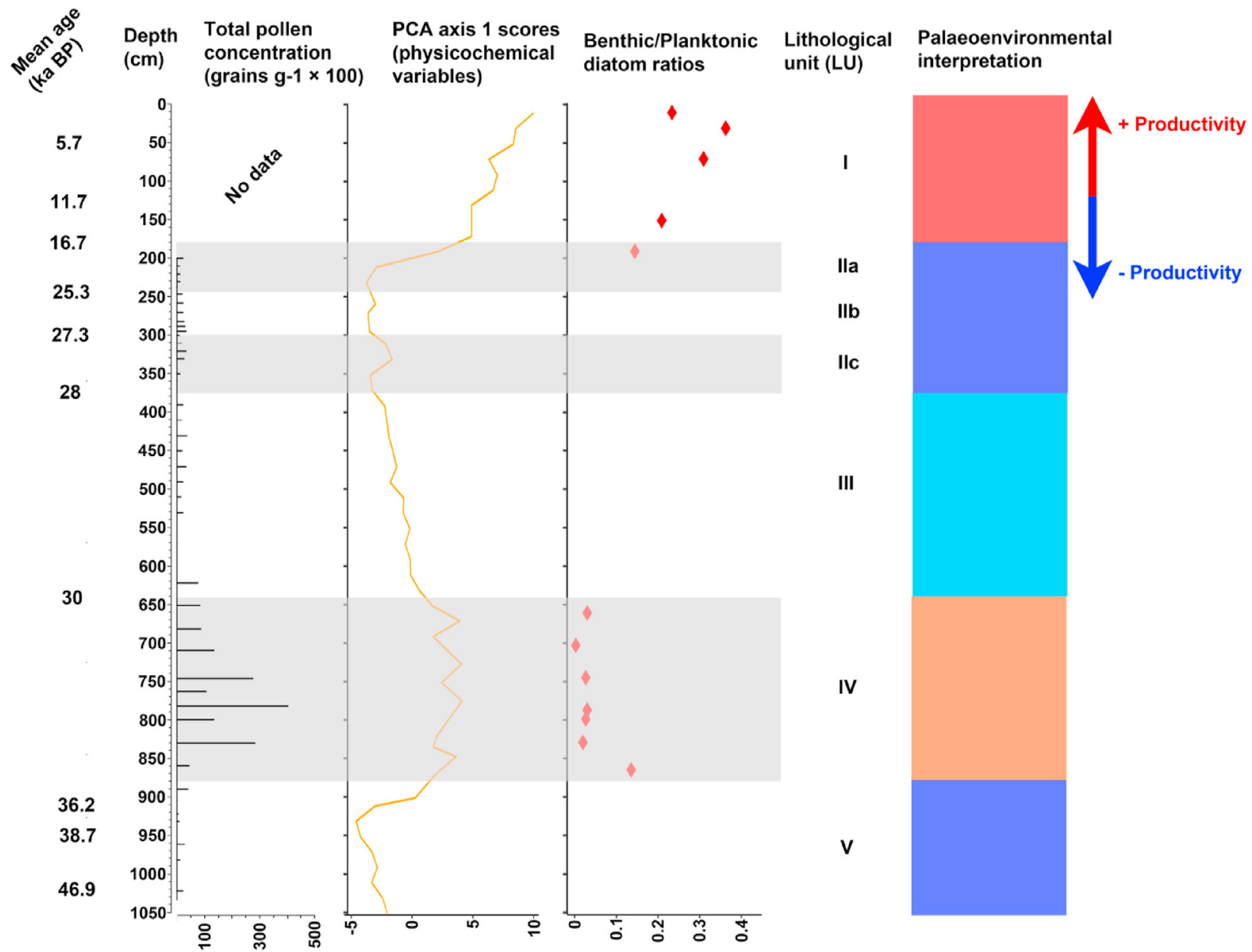

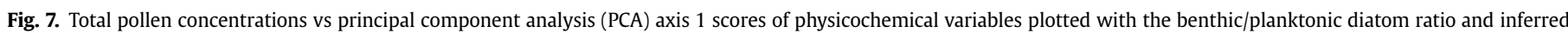
productivity changes from presented proxies.

\subsection{Correlation analysis and ordination of physicochemical sediment variables}

Bivariate Pearson correlation analysis allows the identification of intrinsically linked geochemical and sedimentological variables in core EN18208 (Appendix Fig. 1). Br covaries with organic productivity proxies (TC, TOC, TOC/TN) with a highly significant Pearson's correlation $(p<0.001)$ coefficient with TOC ( $\mathrm{r} 0.82)$, TC ( $\mathrm{r} 0.8$ ) and TOC/TN ratio ( $\mathrm{r} 0.78$ ). The $\mathrm{Mn} / \mathrm{Fe}$ ratio similarly correlates with organic proxies particularly with TOC ( $\mathrm{r} 0.73$ ). $\mathrm{Zr}$ demonstrates a correlation with coarse silt ( $\mathrm{r} 0.51$ ), whereas Ti correlates with very fine silt (r 0.48). K correlates significantly with clay ( $\mathrm{r} 0.82$ ) and to a lesser degree with K-feldspar ( $\mathrm{r}$ 0.39). Al also correlates with clay ( $\mathrm{r}$ 0.79 ). $\mathrm{Zr} / \mathrm{Rb}$ and $\mathrm{Si} / \mathrm{Al}$ ratios covary with mean geometric grain size ( $\mathrm{Zr} / \mathrm{Rb} \mathrm{r}$ 0.49, $\mathrm{Si} / \mathrm{Al} \mathrm{r} \mathrm{0.53)}$ and $\mathrm{Si} / \mathrm{Al}$ with the total silt content ( $\mathrm{r}$ 0.77 ). The K/Ti ratio on the other hand, correlates with clay ( $\mathrm{r} 0.5$ ) and K-feldspar ( $\mathrm{r}$ 0.51). Ca correlates with plagioclase feldspar ( $\mathrm{r}$ 0.63 ), $\mathrm{Sr}$ ( $\mathrm{r} 0.52$ ), very fine-silt (r 0.83 ) and clay (r 0.57). Ordination of physicochemical sediment variables shows clustering of proxies that agrees with observed down core variations and correlation analysis and shows grouping of data according to LU (Figs. 7 and 8). The first two PCA axes together explain $60.6 \%$ of total variance. Variance in the first eigenvector is controlled chiefly by variations in grain-size and organic productivity proxies: mean geometric grain-size, $\mathrm{Zr} / \mathrm{Rb}$, coarse silt, medium silt, Br, TOC, TC and TOC/TN are negatively correlated with clay, very fine silt, and elements and minerals associated with fine-grained fractions ( $\mathrm{Al}, \mathrm{K}, \mathrm{Ca}, \mathrm{Ti}$, plagioclase and $\mathrm{K}$-feldspar/TI, $\mathrm{K} / \mathrm{Ti}$ ). The second eigenvector is influenced by the coarsest grain-size fractions (fine-sand, sand) in the positive direction which are negatively correlated with fine-silt. LUII, LUIII and LUV show overlapping ellipsoids in the negative PCA axis 1 direction associated with fine-grain sizes and low values of productivity proxies. Samples from LUIII are mainly concentrated between very-fine silt to fine silt. Samples from LUII generally plot between very fine-silt and clay fractions and associated elements and minerals. LUV shows similarities to LUII although large scatter exists between samples. LUI is well defined in the positive PCA axis 1 direction with variance controlled by higher organic productivity and grain-size proxies. LUIV lies in the positive PCA axis 2 direction with variance controlled by coarse sediment (sand and coarse silts) and $\mathrm{Zr}$. The biplot is divided into "higher and lower productivity" sections for discussion.

\section{Discussion}

\subsection{Reliability of XRF-derived sediment geochemical proxies}

XRF-based geochemical proxies (Fig. 4) are shown via statistical analyses (Fig. 8, appendix Fig. 1) to effectively represent sedimentological variability exhibited at Ilirney. The significant correlation between $\mathrm{Br}$ and organic productivity proxies affirms $\mathrm{Br}$ as a highresolution proxy of organic productivity in lacustrine sediments 


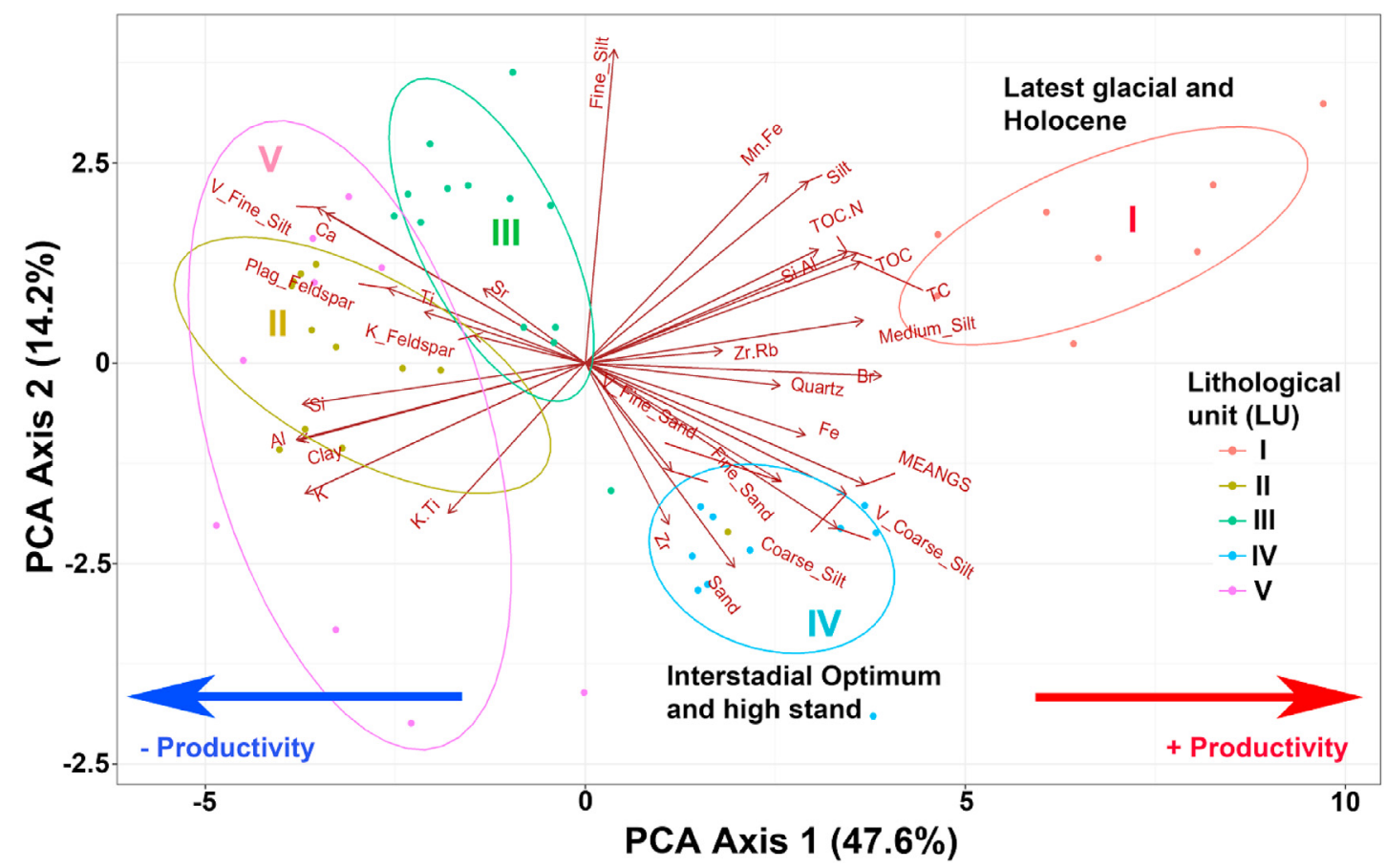

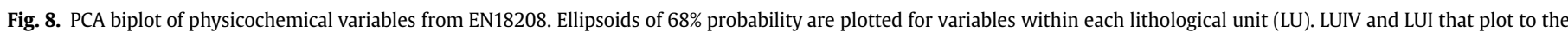
right are associated with higher productivity environmental conditions of varying degree. LUII, LUIII, LUV show common traits of more deteriorated environmental conditions.

(Biskaborn et al., 2013; Fedotov et al., 2012; Flood et al., 2016; Heinecke et al., 2017; Kalugin et al., 2007; Ziegler et al., 2008). Zr is related to the minerogenic input of resistant minerals deposited alongside coarse silt and sand (Cuven et al., 2010; Marshall et al., 2011). Zr here is correlated with coarse silt and reinforces this interpretation. $\mathrm{K}$ and $\mathrm{Al}$ have been used as proxies for variations in clay within lacustrine sediments (Clift et al., 2014; Cuven et al., 2010) and both show significant correlations with clay here. Moderate correlation between $\mathrm{K}$ and $\mathrm{K}$-feldspar/TI implies that K-feldspar contributes also to the response of $K$ variability. Fe distribution is associated with changes in organic productivity proxies and is concentrated within $\mathrm{Fe}-\mathrm{Mn}$ laminations from LUIV and LUI. Plagioclase feldspars contain Ca and hence the correlation with XRF derived $\mathrm{Ca}$ and the absence of carbonate suggests $\mathrm{Ca}$ represents variations in plagioclase feldspar. $\mathrm{Sr}$ can be exchanged with $\mathrm{Ca}$ within the crystal structure of plagioclase feldspars, plausibly indicated by the correlation between $\mathrm{Ca}$ and $\mathrm{Sr}$ (Biskaborn et al., 2013; Kalugin et al., 2007). $\mathrm{Zr} / \mathrm{Rb}$ and Si/Al ratios have been suggested as effective proxies of grain-size variability in lacustrine sediments (Biskaborn et al., 2019a; Chawchai et al., 2016; Thöle et al., 2019) and correlate with mean grain-size here. Si/Al must, however, be viewed critically as Si can be clastic and biogenic in origin being present in quartz and other silicate minerals and being a component of diatom frustules in the form of biogenic opal (Biskaborn et al., 2019b). Si/Al has also been used in studies as a proxy for biogenic silica (Peinerud, 2000). As abundant diatoms occur within LUIV and LUI, Si/Al may be responding to a mixed source related to grain-size and diatoms. A more thorough, quantitative study of diatoms is required to untangle this signal and is beyond the scope of this study. Moreover, $\mathrm{Si}$ and $\mathrm{Al}$ are particularly sensitive to variations in core water content (Tjallingii et al., 2007). $\mathrm{K} / \mathrm{Ti}$ has been considered a useful proxy of physical vs chemical weathering, variations in clastic input of potassium-containing minerals including K-feldspar and as a proxy for grain-size (clay) variability within siliciclastic sediments (Arnaud et al., 2012;
Bouchard et al., 2011; Diekmann et al., 2008; Lenz et al., 2016). Significant correlation between $\mathrm{K} / \mathrm{Ti}$, K-feldspar and clay and the predominance of high $\mathrm{K} / \mathrm{Ti}$ during intervals of deteriorated environment suggests the usefulness of $\mathrm{K} / \mathrm{Ti}$ as a proxy for weathering, clay and feldspar input here. $\mathrm{Mn} / \mathrm{Fe}$ has been used as a proxy for redox conditions in lacustrine settings (Heinecke et al., 2017; Naeher et al., 2013; Pattan, 1993). Higher Mn/Fe values are used to infer increasingly oxic conditions because $\mathrm{Mn}$ is more readily reduced under anoxic conditions than Fe (Balistrieri et al., 1992; Loizeau et al., 2001; Wersin et al., 1991).

\subsection{Sediment biogeochemical and sedimentological proxies}

TOC in lake sediments represents the stability between organic matter degradation, allochthonous input and autochthonous production (Meyers and Teranes, 2005). The TOC/TN ratio is widely interpreted as a proxy of the source of organic matter deposited (Meyers and Lallier-Vergès, 1999). Values above 18 are interpreted as organic matter sourced from vascular plants within the catchment, while values between 10 and 4 indicate predominantly autochthonous algal contribution. TOC/TN ratios from EN18208 reflect productivity mostly driven by lake internal processes. As TOC is very low in Ilirney sediments with no macrophyte remains observed within EN18208, the contribution of catchment organic material is likely very low.

Grain-size analysis can be used to interpret sedimentological processes occurring within the catchment and lake (Prins and Weltje, 1999). It has, however, been widely discussed that grainsize variations may not be representative of a single sedimentary process, but can result from mixing of various sources and transport processes (Heinecke et al., 2017). Increased grain-size recorded within LUIV and LUI are represented by the highest contributions of sand and coarse silt grade material that likely represent deposition in a heterogeneous environment with sediment of mixed source (Dietze et al., 2011). Grain-size variations within these lithological 
units thus could be interpreted to represent increased energy of sediment transport and clastic input possibly via enhanced local fluvial pathways. This may have resulted from the expansion of the catchment drainage area and development of fluvial systems associated with the disappearance of catchment glaciers following glaciation. Significant influence from on-shore processes could also contribute to the signal and may result from the erosion of coarser shoreline sediments through enhanced wave activity and storms during extended phases of reduced lake ice cover leading to sediment reworking and redistribution (Asikainen et al., 2007; Vologina et al., 2003). The effect of wave activity is observed today by the reworking of coastal sediments and the generation of coastal berms at lake Ilirney and at lake El'gygytgyn and may play a large role in the redistribution of coarse material throughout the basin (Juschus et al., 2011; Federov et al., 2019). Surface samples collected from the southern lake shore and northern fluvial inflows show similar grain-size characteristics to samples derived from LUIV and LUI that supports these interpretations (Supplement, Fig. 2). It is also plausible that Aeolian deposition can lead to enhanced deposition of coarse material to the basin during times of reduced lake ice cover (Wang et al., 2015).

Reduced grain-size and increased clay within LUV, LUIIc and LUIIa likely corresponds to low-energy hemipelagic deposition under extended lake ice cover and shares similarities with grainsize distribution three (GSD3) from Lake El'gygytgyn sediments also purported to represent deposition beneath an extended lakesurface ice layer during cold intervals (Asikainen et al., 2007). Enhanced clay deposition may also relate to rock flour input derived from glacial melt, as has been observed at Tibetan glacial lake sites (Wang et al., 2015). Lithological units possessing increased grain-size may also contain signals relating to diatoms present within the sediment, particularly considering that these units predominate at depths where diatoms are most commonly found within smear slides.

\subsection{Reconstruction of Late Quaternary palaeoenvironments at Lake Ilirney}

\subsubsection{Origin of the ilirney basin during MIS4}

Lake Ilirney lies on a south-west to north-east trending structural feature that passes through the Anadyr Mountains to the north, representing a major fault (Zhuravlev et al., 1999)(Fig. 1). Though tectonics played an initial role in the establishment of a weak zone permitting the formation of the basin, the aseismic nature of much of the Chukotka interior suggests a limited role in basin development during the Late Quaternary (Fujita et al., 2002). The lowermost Ilirney sediments (LUVI, AU5) identified from acoustic transects and coring are dated to $53.4( \pm 4.5)$ ka BP representing coarse-grained, moderately sorted, sand and gravel deposits. High feldspar relative to quartz, Ca and $\mathrm{K} / \mathrm{Ti}$ point to deposition of immature material derived from weathering of proximal quartzofeldspathic igneous lithologies from the Anadyr Mountains. Structures within AU5 show similarities to deposits from other glacial lake systems (Lebas et al., 2019) and are interpreted here to represent channels and moraines, suggesting a highenergy, dynamic depositional setting corresponding to a glacialfluvial environment (Fig. 9a). Acoustic penetration within basal sediments was limited with only the upper surface being traced effectively. Terminal moraine deposits at elevations comparable to Ilirney have been observed within the vicinity (Fig. 1a) (Zhuravlev et al., 1999). Satellite and aerial photography in combination with geomorphological field mapping of glacial features across Chukotka has suggested that glaciers during MIS4 were considerably more extensive than during MIS2, with studies suggesting that Chukotka was up to $40 \%$ covered by ice (Elias and Brigham-Grette, 2013;
Glushkova, 2011; Heiser and Roush, 2001; Stauch and Gualtieri, 2008). Geomorphological evidence of moraines to the west of El'gygytgyn indicates that glacial advance during MIS4 was substantial with valley glaciers extending several tens of kilometres from the Anadyr Mountains (Melles et al., 2005). Additional support for a prominent MIS4 glaciation comes from cosmogenic dating of boulders within moraine deposits from the Alaska Range, Brooks Range and Ahklun Mountains (eastern Beringia), which suggest maximum glacial advance $60-50 \mathrm{ka}$ and stabilisation at 52 $\mathrm{ka}$, in agreement with ages from the Ilirney basal sand (Briner and Kaufman, 2008). ${ }^{36} \mathrm{Cl}$ and ${ }^{14} \mathrm{C}$ dating of moraines from the Koryak Mountains of southern Chukotka suggested that preserved moraines $>30$ ka were likely formed as part of glacial advances during MIS4 (Brigham-Grette et al., 2003). Similar basal sand deposits from former glacial lake Billyakh $\left(65^{\circ} 16^{\prime} \mathrm{N}, 126^{\circ} 44^{\prime} \mathrm{E}\right)$ within the Verkhoyansk Mountains, Yakutia have been used to infer the presence of glacial catchment conditions prior to $50 \mathrm{ka}$ BP during MIS4, which resulted in non- lacustrine deposition (Diekmann et al., 2016). During the earliest phase of the Ilirney sediment record we infer the presence of glacial conditions and a valley glacier within the Ilirney catchment at $53.4( \pm 4.5)$ ka BP associated with the MIS4 glaciation, leading to the deposition of highly minerogenic, glaciofluvial outwash deposits throughout the basin (Fig. 9a). Channel structures recorded in acoustic profiles, are evidence of fluvial systems draining the glacier front that were subsequently infilled with postglacial lacustrine sediment (drape) during lake basin evolution (Johnson et al., 1982; Stewart and Lonergan, 2011).

\subsubsection{Initiation of lacustrine deposition during MIS3}

Initiation of lacustrine deposition is reflected by a major physicochemical changeover at the LUVI/LUV transition and by the appearance of reflectors of AU4 (Fig. 2c) dated to $51.8( \pm 4.1) \mathrm{ka}$ BP. Lake initiation was likely connected to the commencement of retreat of the MIS4 glacier (Fig. 9b). The initial lake was likely shallow with considerable clastic sediment input as shown by high mean grain-size, modest clay and higher sand contributions along with high values of clastic input proxies $(\mathrm{Zr})$. These proxies likely document locally sourced fluvial or near-shore clastic input into the shallow lake derived from melt of the glacier front (Dietze et al., 2012). Following an initial shallow phase, increasing clay and decreased grain-size mirrored by XRF proxies ( $\mathrm{Zr} / \mathrm{Rb}$ and $\mathrm{K} / \mathrm{Ti}$ ) may indicate lake deepening. Observation of AU4 in the shallow outflow region supports this and shows that lacustrine deposition in LUV likely became basin-wide with sufficient water-depth to permit contiguous deposition (Fig. 9b). A lack of diatoms and low Br, TC and immeasurable TOC show that within-lake conditions during this time limited bioproductivity. Low local catchment vegetation productivity during this phase is evidenced by very low pollen concentrations.

A quasi-permanent ice layer was likely present on the surface of Lake Ilirney during LUV deposition, as has been reported for El'gygytgyn during phases of cold climate (Asikainen et al., 2007; Melles et al., 2007). This reduced wind-induced currents and lake mixing processes at depth within the water-column thereby allowing the development of lake stratification and suboxic conditions at the sediment-water interface. This may have led to low $\mathrm{Mn} / \mathrm{Fe}$ values that were prevalent throughout LUV, particularly during the onset of lacustrine conditions and around $36.2( \pm 2.6) \mathrm{ka}$ BP (Davison, 1993). Decreasing Mn/Fe values, however may also support deep water, but this effect is inseparable from variations that may result from stratification under quasi-permanent ice cover (Brown et al., 2000; Naeher et al., 2013).

Increased duration of ice cover at the lake surface would have also affected the deposition of clastic material via hemipelagic 


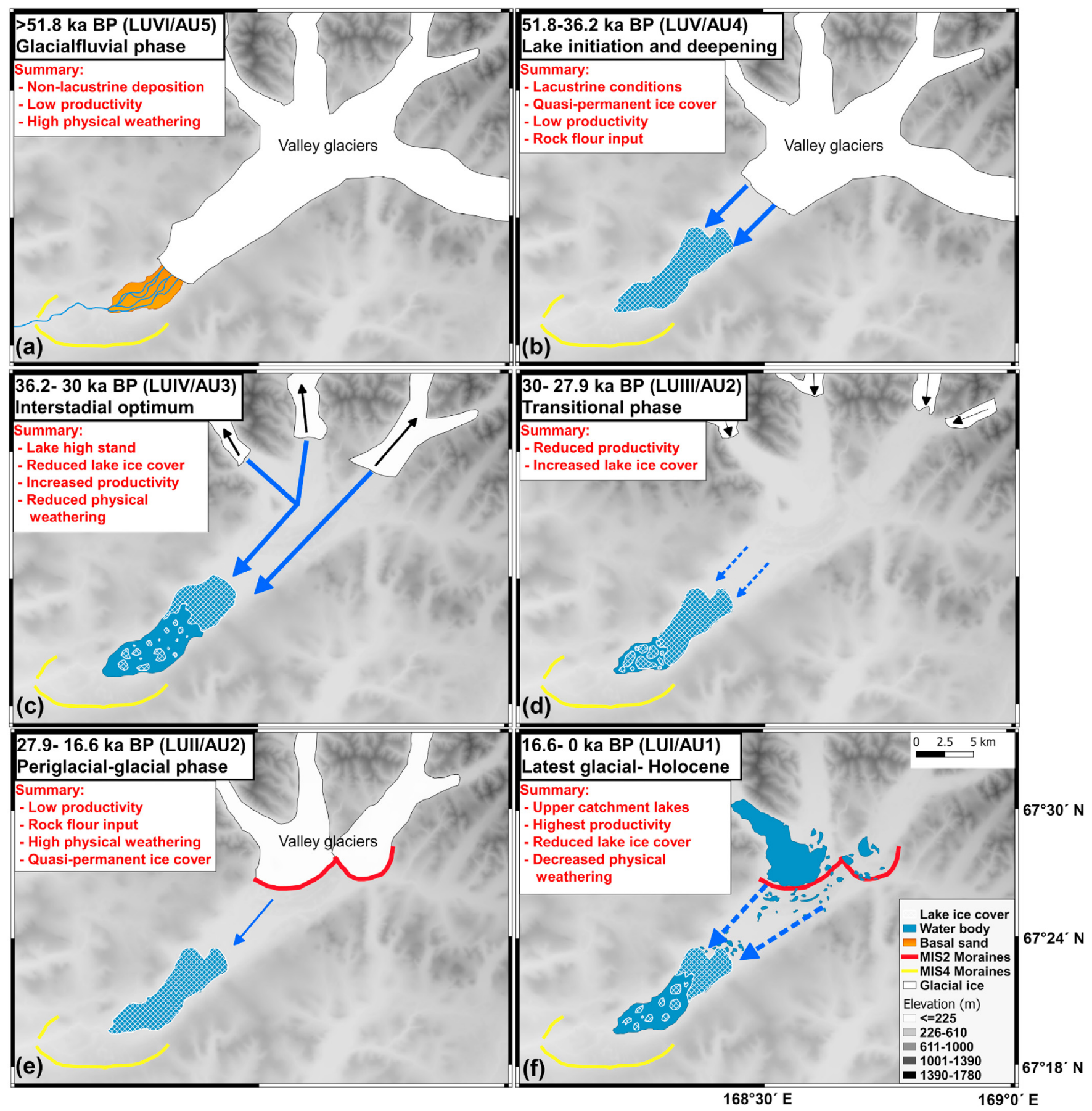

Fig. 9. (a)-(f) Palaeogeographic scenarios during the development of lake Ilirney since 53.4 ka BP to present.

settling with deposition likely only being facilitated at the lake ice margins and/or through cracks in the ice layer during summer (Asikainen et al., 2007; Melles et al., 2007). Settling from suspension was a dominant mechanism of sedimentation as represented by high clay contribution. Reduced deposition of coarser material due to reduced fluvial clastic influx via lake inflows was likely hindered by the absence of an active layer in the catchment (Asikainen et al., 2007; Priscu et al., 1998). Redistribution of shoreline sediments was also likely hampered through reduced wave-activity under the lake ice cover. Reduced sedimentation rates during this period likely contributed to the absence of $\mathrm{Fe}-\mathrm{Mn}$ laminations in the sediments as redox layers need to be buried to prevent dissolution under anoxic conditions (Labuhn et al., 2018; Odegaard et al., 2003; Prokopenko et al., 2001). Physicochemical proxies verify cold, deteriorated environmental conditions with high physical weathering, evidenced by very high $\mathrm{K} / \mathrm{Ti}$ values by 37 $( \pm 3)$ ka BP, associated with increased minerogenic input of feldspars within the clay and very fine silt fraction. Increased feldspars relative to decreased quartz within fine sediment $(<2 \mu \mathrm{m})$ has been attributed to glacial abrasion in sediments derived from the Norris Glacier, Alaska (Nesbitt and Young, 1996). Glacial rock flour at Lake Owens, California, consisted chiefly of clay-sized, feldspar-enriched 
material derived from intense physical weathering by catchment glaciers (Bischoff et al., 1997). A similar mechanism may have existed at Ilirney whereby fine-clastic components were derived from physical weathering of abundant, feldspar-rich lithologies by the glacier. This is supported by the high bulk density of sediments within LUV typical of glacigenic suspended load (Fig. 3a) (Bakke et al., 2005). The input of nutrient poor rock flour from a glacier in addition to the existence of a quasi-permanent ice layer would have contributed to poor conditions for organic productivity in the lake (Benson et al., 1998; Karlén, 1981; Melles et al., 2007; Smol, 1988).

The onset of lacustrine conditions at Ilirney is consistent with regional inferences of the onset of the MIS3 interstadial. Sedimentological and biological evidence from Lake Billyakh (Diekmann et al., 2016), suggests a similar timing to Ilirney for the onset of lacustrine conditions, starting from $50 \mathrm{ka}$ BP. Catchment conditions surrounding Billyakh during initial lacustrine development (50-40 ka BP) were interpreted as been continually influenced by the proximal glaciers within the catchment (Diekmann et al., 2016). Evidence from Yedoma sites from Arctic Yakutia agree with the timing of the onset of the early MIS3 Interstadial between 50 and $48 \mathrm{ka} \mathrm{BP}$ (Wetterich et al., 2014). Despite the onset of the early MIS3 Interstadial, local palaeoenvironmental conditions within the Ilirney basin remained harsh and unfavourable for catchment and within-lake bioproductivity, particularly between $38.7( \pm 3.7)$ and $36.2( \pm 2.6) \mathrm{ka}$ BP. This matches the timing of cold climate phases from early MIS3 records preserved within Alaskan Yedoma deposits (Itkillik River, Fox Tunnel), river bluff deposits (Epiguruk) and lake sediments from Lake Joe (Anderson and Lozhkin, 2001; Lapointe et al., 2017 and references therein). These records suggest that cold environmental conditions persisted until 35-36 ka BP. In addition, middle-late Pleistocene glacial advances from the Brooks Range and Kigluaik Mountains, Alaska preserved within the Itkillik I stage have been interpreted as glaciations prevailing, in the case of the Itkillik IB stage until 35 ka BP before deglaciation (Hamilton, 2001; Hamilton et al., 1986). Anderson and Lozhkin (2001) implied environmental conditions approaching glacial conditions in northwestern Alaska 40-35 ka BP. Palynological data from Lake Alut $\left(60^{\circ} 8^{\prime} \mathrm{N}, 152^{\circ} 19^{\prime} \mathrm{E}\right)$ in southern Chukotka have suggested cold and dry climate conditions persisted until 41 ka BP during MIS3 before giving way to warmer interstadial "optimum" conditions thereafter (Lozhkin, 2002). Sediments from LUV at Ilirney thus represent lacustrine development and deepening under cold, low productivity environmental conditions affected by the presence of a catchment glacier during the early MIS3.

\subsubsection{Evidence for a MIS3 lake high-stand}

A major transition is evidenced by dramatic changes in proxies beginning 36.2 ( \pm 2.6$)$ ka BP. Increases in grain-size, $\mathrm{Zr} / \mathrm{Rb}, \mathrm{Si} / \mathrm{Al}$, silt and sand, along with Br, TC and TOC in the uppermost LUV and LUIV suggest a transition to more favourable environmental conditions (Figs. 7, 8 and 9c). TOC/TN ratios of below 7.5 indicate lake bioproductivity was driven by internal lake dynamics (Meyers and Teranes, 2005). Abundant planktonic diatoms led to low benthic/ planktonic diatom ratios throughout LUIV implying high lake levels during this time with limited habitat availability for benthic taxa (Heinsalu et al., 2007; Wang et al., 2011; Wolin and Stone, 2010). Lake-level reconstructions from El'gygytgyn have been used to imply that lake levels were high following MIS4 leading to the formation of a lacustrine terrace $9-11 \mathrm{~m}$ above the current lakelevel (Fedorov et al., 2019; Glushkova and Smirnov, 2007). Though the timing of the lake high-stand was not effectively constrained due to the lack of a reliable age model at El'gygytgyn, high lake levels represented favourable conditions that occurred during MIS3 (Juschus et al., 2011). Sediments from Lake Billyakh show evidence for a MIS3 deep-lake stage 40-30 ka BP associated with abundant planktonic diatoms and high sedimentation rates $\left(0.62 \mathrm{~mm} / \mathrm{yr}^{-1}\right)$ linked to increased runoff, possibly due to enhanced deglaciation (Diekmann et al., 2016). A similar scenario may be inferred at Ilirney within LUIV, where high lake levels likely followed enhanced glacial retreat following the previous phase. Deep lacustrine conditions are supported by low Mn/Fe values indicating suboxic sediment conditions (Heinecke et al., 2017). A possible lake terrace $15 \mathrm{~m}$ above the current lake level on the northern shoreline, consisting of sub-rounded gravel and pebbles (Fig. 10), may support a lake high-stand.

Pollen concentration variations imply changes in catchment vegetation productivity across the LUV/LUIV transition and within LUIV (Andreev et al., unpublished data; Peros and Gajewski, 2008; Wetterich et al., 2014). Increasing pollen concentrations from LUV to LUIV suggest increased productivity from catchment vegetation that culminated $33-30.8 \mathrm{ka}$ BP.

Prominent, but occasionally discontinuous, sub-horizontal reflectors within AU3 across the entire lake basin corroborate prevalent lacustrine deposition under deep-water conditions. The occasional discontinuity and variable amplitude of reflectors may be related to variations in bulk density within LUIV (Fig. 3a) (Anselmetti et al., 2009). Similar deposits to AU3 have been found during seismic profiling at Lake Levinson-Lessing on the Taymyr Peninsula and were used to infer increased sedimentation under conditions of enhanced fluvial deposition that led to increased deposition of turbidite sediments within a lacustrine setting (Lebas et al., 2019). A thin sand layer recorded at $884 \mathrm{~cm}(34.6( \pm 2) \mathrm{ka}$ BP) may provide evidence of a turbidite-like deposit based on similarities to turbidites recorded within the El'gygytgyn sediment core record (Juschus et al., 2009).

Decreased clay implies fine-grained depositional settling from suspension under quasi-permanent lake ice cover and probable rock flour input from proximal glacial abrasion became significantly less dominant. Instead, a reduced duration of lake ice cover was likely with longer ice-free summers, as has been inferred from El'gygytgyn sediments during MIS3 (Asikainen et al., 2007; Melles et al., 2007; Minyuk et al., 2007). The glacier present during the deposition of LUVI and LUV likely retreated to higher elevations or

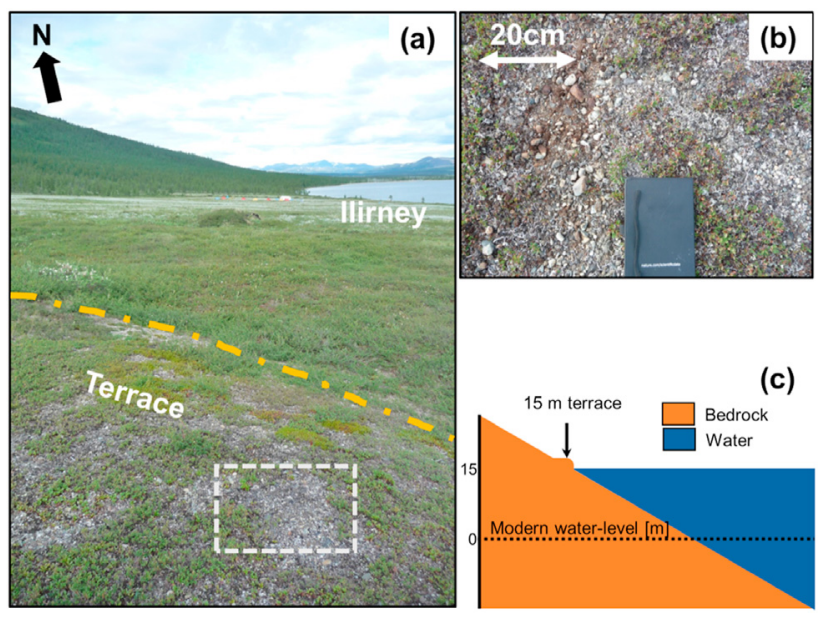

Fig. 10. (a) Image of a probable lake-terrace at Ilirney. The strike of the shoreline is shown by the dashed yellow line. (b) Image of beach gravel, pebbles and sand that constitutes the terrace. (c) Simple model of the lake-level high-stand compared with the modern level. (For interpretation of the references to colour in this figure legend, the reader is referred to the Web version of this article.) 
disappeared completely (Fig. 9c). Increased grain-size, reinforces potentially mixed sources of clastic input including intensified wave-driven shoreline erosion, enhanced fluvial and local aeolian input during extended ice-free summers (Dietze et al., 2012; Vandenberghe, 2013; Wang et al., 2015). Decreasing K/Ti, feldspars and increased quartz support diminishing physical weathering and rock flour input and increased grain-size. Increased quartz during LUIV may relate to increased input of fluvial or aeolian sediment. Detrital quartz input has been shown to be a useful proxy for increased fluvial or aeolian transport due to its resistance to weathering relative to feldspars and thus over representation in mature transported material (Dean, 1997; Yamada, 2004). Stable, low $\mathrm{Mn} / \mathrm{Fe}$ values suggest that, despite increased prevalence of icefree summers, the sediment was suboxic with water column stratification, at least during the early part of LUIV until $30.7( \pm 0.5)$ ka BP (Cohen, 2003; Heinecke et al., 2017). Observance of thermal stratification during 2018 (Supplement, Fig. 1) following surface ice-layer break-up during summer shows that stratification can exist under extended summer ice-free conditions. Stratification was postulated for the MIS3 deep-lake stage at Lake Billyakh on the basis of increased Zn within sediments (Diekmann et al., 2016). The most prominent visual feature of the transition to LUIV sediments is the appearance of $\mathrm{Fe}-\mathrm{Mn}$ laminations. High Fe within laminations corresponds with pyrite $\left(\mathrm{FeS}_{2}\right)$, confirmed by the observance of arsenopyrite (FeAsS) within XRD samples and by colour change of laminations during core opening resulting from oxidation (Labuhn et al., 2018). The origin of Fe-Mn laminations has been discussed by several authors. Iron-sulphide bands deposited within the Great Lakes and in sediments deposited along the southern coast of Finland have been interpreted as evidence of hypoxic to anoxic bottom water or sediment conditions resulting from intensified thermal stratification under ameliorated climate (Odegaard et al., 2003; Pitkänen et al., 2001). Gromig et al. (2019) observed similar Fe-Mn laminations within Lake Ladoga sediments, which represent preserved redox layers resulting from enhanced allochthonous and/or autochthonous organic matter that led to suboxic conditions in near-surface sediments. Redox laminations thus support the interpretation of suboxic conditions at the sediment-water interface. The sporadic appearance of vivianite concretions within LUIV, a further proxy of suboxic sediment conditions, that is often associated with organic material, may reinforce this hypothesis (Asikainen et al., 2007; Labuhn et al., 2018; Rothe et al., 2016). Vivianite however may also form during post-depositional secondary diagenetic processes and therefore may not be contemporaneous with the sediment water interface conditions at the time of deposition (Rothe et al., 2016). Enhanced clastic input could also have contributed to the burial and preservation of laminations before dissolution could occur, as was likely the case during intervals of reduced productivity (Prokopenko et al., 2001).

Variations in PCA axis 1 scores (Figs. 7 and 8) within LUV support environmental improvement, chiefly observed in proxies for enhanced clastic sediment input and within-lake organic productivity that encapsulate a more productive palaeoenvironment following the preceding comparably unfavourable conditions. Evidence for climatic improvement during the MIS3 Interstadial is recorded across Beringia from lake sediment and Yedoma deposits. Multiproxy palaeobotanical and sedimentological studies from eastern Beringia indicate enhanced environmental conditions that commenced $\sim 35 \mathrm{ka}$ BP. This includes lacustrine pollen records from Joe Lake, Alaska (Anderson et al., 1994) where a transition from cold conditions during MIS3 to warmer and wetter conditions begun 35 ka BP, synchronous with river exposure data from the nearby Epiguruk site (Hamilton and Ashley, 1993). The accretion of palaeosols recorded at the Itkillik river, Alaska following the Itkillik IB glacial advance agrees with this timing of the onset of favourable conditions ( $35 \mathrm{ka} \mathrm{BP})$ and lasted until the start of the last glacial maximum (Hamilton, 2001; Hamilton et al., 1986). Recent insights from Alaskan Yedoma deposits support warm MIS3 interstadial conditions 36-30 ka BP (Lapointe et al., 2017). On the other hand, palynological records from western Beringia suggests improved MIS3 interstadial conditions may have already occurred beginning $50 \mathrm{ka}$ BP following the MIS4 glaciation although some regions such as surrounding Lake Alut did not display improved conditions until after 41 ka BP (Lozhkin and Anderson, 2011). Yedoma deposits from the Lena delta region in northern Yakutia imply MIS3 interstadial optimum conditions existed between 40 and $32 \mathrm{ka} \mathrm{BP}$ (Schirrmeister et al., 2002; Wetterich et al., 2014, 2008 and references therein). The timing of a MIS3 interstadial optimum has, however, been said to represent "its own set of mysteries" manifested by spatial and temporally variable palaeoclimatic trends over about 20000 yr (Lozhkin and Anderson, 2011). Despite large chronological uncertainties associated with dating organically poor, lacustrine sediments in Chukotka (Anderson et al., 2010; Anderson and Lozhkin, 2001, 2015'bib_Anderson_and_Lozhkin_2015'bib_Anderson_and_ Lozhkin_2001; Colman et al., 1996; Lozhkin et al., 2007; Lozhkin and Anderson, 2011), proxies here support the presence of a lake high-stand coincident with the timing of improved MIS3 interstadial conditions beginning $36.2( \pm 2.6) \mathrm{ka}$ BP.

\subsubsection{Post MIS3 interstadial optimum transitional environment}

Decreasing PCA axis 1 scores controlled predominantly by grainsize proxies from LUIV to LUIII and by increases in Ca, plagioclase feldspar, clay and disappearance of diatoms and reduced pollen concentrations indicate progression to an increasingly unfavourable environment for productivity from $30( \pm 0.6) \mathrm{ka}$ BP. The PCA biplot (Fig. 8) shows that LUIII represents a transitional phase between the full periglacial-glacial conditions of MIS2 and the preceding interstadial optimum environment. Reflectors within AU2 are high amplitude and continuous throughout the basin indicating basin-wide deposition under deep-water conditions (Lebas et al., 2019). An increased duration of lake ice cover in addition to reduced active-layer thickness relative to the interstadial optimum may have led to increased dominance of finer-grained, hemipelagic sediment represented by grain-size proxies (Asikainen et al., 2007). Increased but highly variable $\mathrm{Mn} / \mathrm{Fe}$ implies variable oxygenation with progressively reduced conditions towards the end of LUIII by $27.9( \pm 0.8) \mathrm{ka}$ BP. The absence of $\mathrm{Fe}-\mathrm{Mn}$ laminations signifies unfavourable conditions for their generation and/or preservation. Continued sporadic appearance of vivianite may imply intermittent reducing conditions at the sediment surface (Nealson, 1997). Catchment glaciers may have already begun to regrow or extend from mountain cirques within the upper catchment during this phase leading to some reworking of catchment material that may provide one possible explanation for the observation of mixed ages predominantly found within LUIII.

\subsubsection{Environmental deterioration during MIS2}

The LUIII/LUII transition represents a change in palaeoenvironment likely consistent with the establishment of periglacial-glacial conditions during MIS2 (Fig. 9e). The transition, based on highresolution XRF data, is manifest by decreased grain-size and increased physical weathering beginning $27.9( \pm 0.8)$ ka BP. Suboxic conditions returned, and within-lake productivity remained low. Increased feldspar input relative to quartz, with higher clay contribution, plausibly represents rock flour input derived from the presence of a catchment valley glacier. A return to similar paleoenvironmental conditions as those proposed for LUV is supported 
by the overlap of the LUV and LUII ellipsoids seen in the PCA biplot (Figs. 7 and 8). Lacustrine deposition likely continued under relatively deep-water conditions denoted by the continuation of prominent acoustic reflectors throughout the basin within the upper parts of AU2 alongside reduced grain-size (Lebas et al., 2019). Evidence for lake-level changes at El'gygytgyn during MIS2 agrees with the initially high lake levels suggested by Glushkova and Smirnov (2007) based on riverine and lake terraces. Juschus et al. (2011) inferred that lake levels were generally high during the early MIS2 but lower thereafter, before rising rapidly at the MIS2 termination. Sedimentation at Ilirney during MIS2 is comparable to that observed during deposition of LUV and is influenced by quasipermanent lake ice cover, contributing to fine-grain sizes observed throughout LUII. Radiocarbon dating of organic matter and wood fragments and cosmogenic surface exposure ages indicate that ice in Chukotka during MIS2 was already at a maximum extent between 27 and 20 ka BP (Brigham-Grette et al., 2003). Similarly, ice advanced within the Brooks Range (Alaska) around 28 ka BP associated with the Itkillik II glaciation in eastern Beringia before reaching maximum extent between 27 and 21 ka BP (Hamilton, 1986, 2001; Lapointe et al., 2017). Evidence for glaciation during MIS2 within the Ilirney catchment comes from terminal moraines present to the north-east of Lake Ilirney (Figs. 1a and 9f). Though these moraines lack absolute age control, relative dating of moraines within Chukotka suggest an origin during MIS2 (Melles et al., 2005). Preliminary ages of dated glacial-fluvial basal sediments from a moraine-dammed glacial lake to the north of Ilirney confirm catchment glaciation by 28 ka BP during MIS2 (Vyse et al., unpublished data). MIS2 pollen data from lake El'gygytgyn indicates open tundra and steppe-like communities with July temperatures considerably less than modern (Lozhkin et al., 2007).

Evidence for local environmental variability following the establishment of MIS2 periglacial-glacial conditions is evident within grain-size and clastic input proxies' $27.6( \pm 0.9)$ to $25.3( \pm 1)$ ka BP. Grain-size increases were governed by increased silt and decreased clay and mirrored by $\mathrm{Zr} / \mathrm{Rb}$ and quartz. Moreover, $\mathrm{K}$ feldspar, $\mathrm{K} / \mathrm{Ti}, \mathrm{Ca}$ and to a lesser extent, plagioclase have increased values in LUIIb. The explanation for this phase is complex as regional palaeoenvironmental data do not suggest environmental change under periglacial-glacial conditions during MIS2 (Lozhkin et al., 2007; Lozhkin and Anderson, 2006). The available data do not allow a full understanding of causation, however one explanation may be that variations in grain-size and clastic input proxies during this interval are related to catchment glacier dynamics. A similar explanation was postulated for Lake Kalakuli in western Tibet based on a similar response of physicochemical proxies and was used to infer periods of glacial advancement and retreat (Liu et al., 2014). This hypothesis is given support by the finding of a coarse, sub-angular, striated quartz grain within LUIIb (Fig. 6a and b) sediments. Striations could represent fractures produced by mechanical abrasion beneath the catchment glacier and have been observed in glacial sediments (Mahaney, 2011). High bulk density of LUIIb sediments supports glacigenic sediment input (Bakke et al., 2005).

\subsubsection{The last glacial maximum (LGM) and the initiation of glacial} retreat

The LGM as reflected by physicochemical variables, pollen concentrations and PCA axis 1 scores, likely occurred close to the LUIIb/LUIIa transition, dated here between $25.5( \pm 0.9)$ to $21.7( \pm 0.7)$ ka BP. The age of the LGM coincides with ${ }^{36} \mathrm{Cl}$ dated MIS2 moraines in Chukotka, which reveal maximum glacier extents between 26 and $11 \mathrm{ka}$ (Gualtieri et al., 2000). Climate conditions at lake Ilirney were likely cold and arid indicated by high amounts of Selaginella rupestris spores (Andreev et al., unpublished data). Our data suggest that the lake-level may have generally remained high during the LGM though we cannot rule out some lake-level lowering that may have affected the shallower parts of the lake that resulted from increased aridity. Local environmental conditions were dominated by high physical weathering and glacial abrasion in the catchment, leading to increased deposition of rock flour, as represented by contributions of clay and high $\mathrm{K} / \mathrm{Ti}$. Within-lake bioproductivity reached low levels, comparable with LUV. A sudden event recorded by $\mathrm{Si} / \mathrm{Al}$ and $\mathrm{Zr} / \mathrm{Rb}$ at $22.5( \pm 0.7)$ ka BP suggests a short-term depositional event, possibly related to a sudden increase in glacial meltwater connected to the beginning of glacier destabilisation prior to deglaciation. Suboxic sediment conditions prevailed alongside reduced sedimentation rates and signify the presence of a quasi-permanent ice layer.

The initiation of glacier retreat is distinguished by dramatic changes in sediment deposition and commenced at Ilirney 20.2 $( \pm 0.8) \mathrm{ka}$ BP as best observed in the high-resolution geochemical records of grain-size and clastic input $(\mathrm{Zr} / \mathrm{Rb}, \mathrm{Si} / \mathrm{Al})$. Evidence for Beringian glacial retreat from the Alaska and Ahklun ranges has advocated commencement between 20 and $19 \mathrm{ka}$ BP (Briner and Kaufman, 2008; Hughes, 1983), whereas ${ }^{36} \mathrm{Cl}$ dating of moraines within the Nygchekveem valley in central Chukotka suggest onset of deglaciation between 21.65 and 11.59 ka BP (Brigham-Grette et al., 2003). Though records of the commencement of deglaciation can vary temporally and spatially (Ehlers et al., 2018, 2011) the commencement at Ilirney is consistent with other Beringian records. Glacial retreat led to the development of moraine-dammed, proglacial lakes in front of the retreating ice-front within the catchment (Figs. 1a and 9f). The development of fluvial systems draining the retreating glaciers and proglacial lakes (Fig. 1a) increased the contribution of sand and silt to the recorded grainsize signal. Decreasing physical weathering and glacial abrasion under ameliorating conditions resulted in reduced clay deposition and likely rock flour input into the lake basin. Increased lake ventilation due to the increasing length of the ice-free season is postulated by steeply increasing Mn/Fe values (Fig. 4b). Rising sedimentation rates likely contributed to the preservation of $\mathrm{Fe}-\mathrm{Mn}$ laminations. Within-lake bioproductivity responded to ameliorating conditions as shown by the re-emergence of diatoms and shifts in organic productivity proxies. Vegetation response to deglaciation marked by increases in Betula pollen is not evident at Ilirney and broader Chukotka until around $15 \mathrm{ka} \mathrm{BP}$ and lags behind initial responses in lake geochemistry and sedimentology presented in this study (Andreev et al., unpublished data; Brubaker et al., 2005; Edwards et al., 2005). Recent evidence from sedimentary DNA preserved in lake sediments on Southern Baffin Island support delayed vegetational responses of Betula of $\sim 3 \mathrm{ka}$ compared to the timing of local deglaciation that was interpreted to result from inefficient seed dispersal and vegetation migration lags (Crump et al., 2019; Shakun et al., 2015). Moreover, recent multivariate analyses of pollen data from El'gygytgyn suggest that lags between climate amelioration and vegetation following glacial conditions can persist for several millennia (Herzschuh et al., 2016). The rapid response of sediment-geochemical and sedimentological proxies to deglaciation may reflect the direct reaction to the initiation of glacial retreat within the catchment. The persistence of harsh catchment conditions and the absence of significant catchment landscape factors necessary for substantial vegetation development during early deglaciation, such as limited soil development, could have resulted in a delayed response of vegetation to early amelioration (Engstrom and Hansen., 1985).

\subsubsection{The late glacial}

Proxies of clastic input via fluvial pathways increase throughout the late glacial and culminate in a maximum around $13.7( \pm 0.6) \mathrm{ka}$ 
BP. During the late glacial, lake-level likely increased due to the retreat of glaciers, recorded by the higher presence of Botryococcus algae remains $\sim 13$ ka BP suggesting a wide availability of shallow, shoreline habitats an extension of wide littoral habitats likely within the extended shallow outflow region (Andreev et al., unpublished data). Lake-level rise may have been permitted by the establishment of coastal berms that blocked the narrow $(<20 \mathrm{~m}$ wide) outflow river that has similarly been proposed for facilitating lake-level high stands at lake El'gygytgyn during warm intervals (Juschus et al., 2011; Federov et al., 2019). This was suggested to have resulted from enhanced wave-driven sediment redistribution towards the outflow during periods of extended ice-free summers. Such a mechanism is plausible given the presence of modern-day coastal berms around the lake Ilirney shoreline and at the outflow river which partially block the channel at the northern bank (Supplement Fig. 5). Abundant diatoms and high values of $\mathrm{Br}$ imply concomitantly high bioproductivity during the late glacial. Low K/Ti implies diminished physical weathering and reduced clay deposition. Regional pollen data have shown that vegetation during this time was dominated by the continued establishment of Betula and the appearance of shrub alder (Alnus fruticosa) starting around 14-13 ka BP (Brubaker et al., 2005). Local pollen concentration increases suggest gradually increasing pollen production during this time (Andreev et al. unpublished data). Pollen data are interpreted to represent climate amelioration during the late glacial and agree with physicochemical data presented in this study. Evidence for an early start to amelioration prior to the Pleistocene/Holocene boundary has been recognised within several prominent Chukotkan palynological records from the Kankaren Range and Anadyr lowlands in southern Chukotka that accompanied a 7\% increase in orbitally driven insolation (Anderson and Lozhkin, 2015; Lozhkin and Anderson, 2013, 2011; Nowaczyk et al., 2007).

High-resolution geochemical data obtained from Lake Ilirney show no evidence of a return to glacial conditions associated with a strongly pronounced Younger Dryas (YD) cooling. Evidence of enhanced physical weathering and clay deposition is not found, nor is there significant reduction of within-lake bioproductivity that would imply colder, unfavourable conditions. A small reversal in the $\mathrm{Mn} / \mathrm{Fe}$ trend alongside reducing $\mathrm{Si} / \mathrm{Al}$ and $\mathrm{Br}$ from $12.5( \pm 0.5) \mathrm{ka}$ BP may indicate some local change in environmental conditions. The magnitude of this change is however not comparable to suggestions of climate cooling proposed for other records within northern parts of Chukotka including El'gygytgyn (Andreev et al., 2012) and Wrangel Island (Lozhkin et al., 2001). Palynological records from southern Chukotka and a lack of moraines of YD age within the Brooks Range (eastern Beringia) provide evidence of a subdued YD within other parts of Beringia (Anderson and Lozhkin, 2015; Ehlers et al., 2011; Hamilton, 2001). Palynological records from eastern Yakutia also suggest a lack of a pronounced YD cooling (Lozhkin et al., 2018). An appraisal of the cause of the reduced prominence of the YD is beyond the scope of this study and may be related to variable effects of local modifiers (topography, soil, sediment disturbance) on large-scale climatic forcing between palaeorecord sites (Kokorowski et al., 2008).

\subsubsection{The holocene}

A clear transition to the Holocene at $\sim 11.7 \mathrm{ka} \mathrm{BP}$ is not observed in most physicochemical proxies at Ilirney. The transition is marked only by non-substantial increases in $\mathrm{Mn} / \mathrm{Fe}, \mathrm{Si} / \mathrm{Al}$ ratios and increased sand. A more pronounced transition is however observed by dramatic increases in pollen concentrations observed within core 16-KP-01-L02 (Andreev et al., unpublished data).

Holocene sediments demonstrate continuously increasing TOC alongside $\mathrm{Br}$ and high diatom percentages indicating increasing within-lake bioproductivity (Fig. 9f). Increasing TOC/TN values above those observed in LUIV and LUIII suggest a mixed source of organic material with a higher contribution from terrestrial sources towards present, though the predominant source remained algal (Meyers and Lallier-Vergès, 1999). $\mathrm{Mn} / \mathrm{Fe}$ values increase throughout the Holocene towards the sediment surface, probably representing ventilation of the water column associated with prolonged ice-free summers due to climate amelioration. Persistently high $\mathrm{Zr} / \mathrm{Rb}$ and $\mathrm{Si} / \mathrm{Al}$ alongside increased grain-size plausibly supports reduced lake ice cover with enhanced clastic input from wave-driven shoreline erosion, fluvial and aeolian input. Prominent $\mathrm{Fe}-\mathrm{Mn}$ laminations imply intermittent stratification and suboxic sediment conditions (Fig. 5) that were likely preserved by higher sedimentation rates. Dominance of planktonic relative to benthic diatom taxa suggests high lake-levels persisted throughout most of the Holocene. Benthic/planktonic ratios were however higher than those recorded during the MIS3 interstadial optimum, suggesting that Holocene lake fluctuations did not reach levels comparable to MIS3. Decreased summer ice cover under Interglacial conditions may also have contributed to higher abundances of benthic diatoms in Holocene sediments (Fritz and Anderson, 2013; Smol, 1988). Evidence for lake-level variability during the Holocene is seen by erosional truncation of acoustic reflectors belonging to AU2 and the pinching out of AU1 reflectors at water depths $<10 \mathrm{~m}$. The occasional absence of AU1 in the shallow outflow area is evidence of subaerial exposure of older sediments with subsequent erosion. Evidence from El'gygytgyn has suggested that lake levels during the Holocene were initially high but decreased progressively (Fedorov et al., 2019; Glushkova and Smirnov, 2007; Juschus et al., 2011). Recent lake-level variability is evidenced by the absence of significant deposition of AU1 on top of sediments in shallow areas.

\section{Conclusions}

Studies of sediment core EN18208 provide detailed insight into the palaeoenvironmental development at Lake Ilirney since $\sim 53.4$ ka BP. Based on the results, we derive the following conclusions:

- XRF-based sediment-geochemical proxies effectively represent sedimentological (organic content, grain-size, mineralogy (feldspars)) variables, elucidating their application for reconstructing palaeoenvironmental dynamics in arctic lakes.

- Proxies recorded within lake Ilirney sediments respond to late Quaternary climate induced lake catchment changes brought about by changing glacial and runoff dynamics as well as within-lake changes including climate-controlled variability in the duration of lake ice cover.

- Data presented in this study imply that the Ilirney basin originated from glacial processes during an extensive MIS4 glaciation.

- Lake initiation commenced at $51.8( \pm 4.1) \mathrm{ka}$ BP during MIS3 but local environmental conditions within the catchment remained unfavourable for bioproductivity until $36.2( \pm 2.6)$ ka BP.

- A lake high-stand coinciding with the MIS3 interstadial optimum as defined by Beringian Yedoma, lacustrine and river-bluff records suggests favourable environmental conditions for within-lake and local catchment bioproductivity with deposition in a deep-lake setting. Multiple physicochemical proxies evidence increased clastic to the lake during this time likely through mixed sources.

- Following a post-interstadial transitional stage of deteriorating palaeoenvironmental conditions, a return to periglacial-glacial conditions during MIS2 at $27.9( \pm 0.8)$ ka BP is inferred. A prominent valley glacier was present during this time but was not as extensive as during MIS4. 
- Glacial retreat, as recorded by dramatic shifts in sedimentgeochemical proxies, began at $20.2( \pm 0.8)$ ka BP and responded rapidly to deglaciation compared with vegetation. Glacial retreat led to the formation of moraine-dammed glacial lakes in the catchment.

- There is limited evidence for a pronounced Younger Dryas event within the Ilirney records, in line with findings from other sites across Beringia.

\section{Author statement}

Boris Biskaborn and Ulrike Herzschuh designed the study and

\section{Data availability}

Data used in this study is accessible from the PANGAEA data repository (link: https://doi.pangaea.de/10.1594/ PANGAEA.915562).

\section{Declaration of competing interest}

The authors declare that they have no known competing financial interests or personal relationships that could have appeared to influence the work reported in this paper.

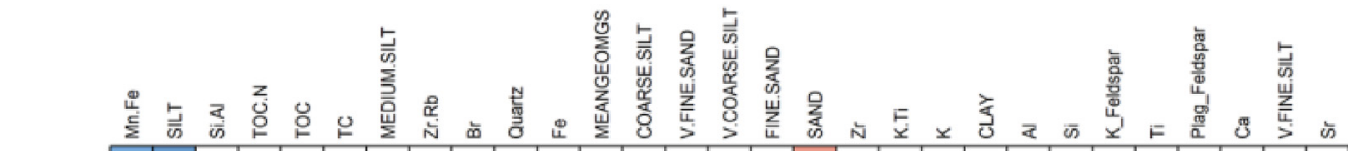

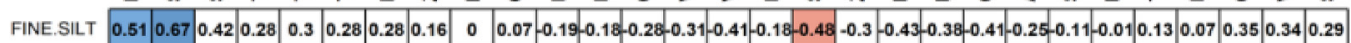

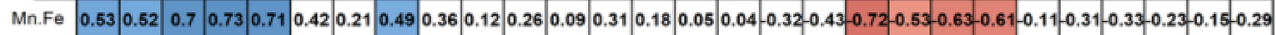

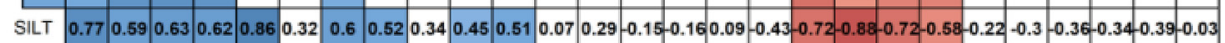

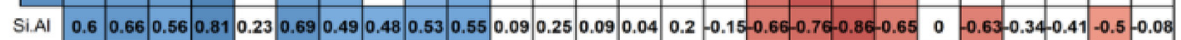

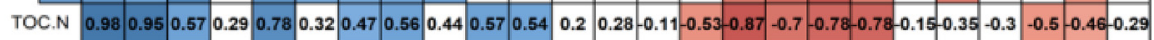

$$
\begin{aligned}
& \text { TOC } 0.960 .63 \quad 0.27 \quad 0.820 .34 \quad 0.5 \quad 0.590 .46 \quad 0.56 \quad 0.53 \quad 0.24 \quad 0.29-0.13-0.48-0.88-0.74-0.81-0.8-0.14-0.42-0.35-0.54-0.49-0.35
\end{aligned}
$$

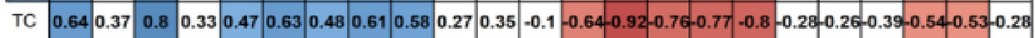

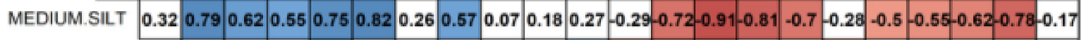

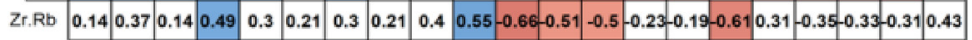

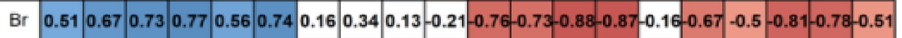

$$
\begin{aligned}
& \text { Quartz } 0.25 \mid 0.48 \quad 0.58 \quad 0.17 \quad 0.51-0.18 \quad 0.1 \quad 0.38-0.06-0.4-0.55-0.48-0.4-0.41-0.42-0.78-0.59-0.54-0.2
\end{aligned}
$$

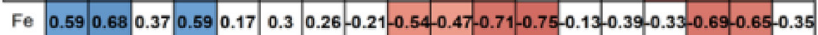

$$
\begin{aligned}
& \text { MEANGEOMGS } 0.84 \quad 0.68 \quad 0.83 \quad 0.55 \quad 0.77 \quad 0.44-0.3-0.62-0.8-0.65-0.63-0.37-0.37-0.59-0.78-0.92-0.18 \\
& \begin{array}{lllllllllllllll}
\text { COARSE.SLT } & 0.43 & 0.82 & 0.11 & 0.42 & 0.51 & -0.1 & 0.51 & -0.7 & 0.65-0.62 & -0.3 & -0.52-0.56-0.83 & -0.94 & -0.29
\end{array} \\
& \text { V.FINE.SAND } 0.790 .570 .750 .01-0.3-0.48-0.42-0.38-0.52-0.25-0.19-0.32-0.56-0.57-0.37 \\
& \text { V.COARSE.SILT } 0.26 \quad 0.62 \quad 0.35-0.2-0.52-0.57-0.53-0.64-0.41-0.37-0.55-0.85-0.87-0.41 \\
& \text { FINE.SAND } 0.820 .07-0.18-0.19-0.24-0.15-0.17-0.060 .02-0.13-0.15-0.330 .09 \\
& \text { SAND } 0.33-0.19-0.27-0.32-0.21-0.29-0.27-0.07-0.36-0.51-0.62-0.06 \\
& \text { Zr } 0.01-0.04-0.25-0.17-0.12-0.33-0.07-0.3-0.47-0.440 .36 \\
& \begin{array}{cccccccccccc}
\hline \text { K.Ti } & 0.74 & 0.5 & 0.35 & 0.43 & 0.51 & -0.5 & 0.13 & 0.08 & 0.14 & 0.34 \\
\hline
\end{array}
\end{aligned}
$$

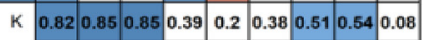

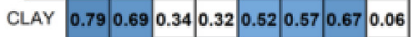

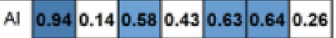

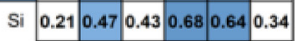

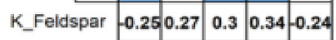

$$
\begin{aligned}
& \begin{array}{l|l|l|l|l|l|}
\hline \text { Ti } & 0.3 & 0.54 & 0.48 & 0.61
\end{array} \\
& \begin{array}{ll|lll}
\text { Plag_Feldspar } & 0.63 & 0.6 & 0.29 \\
\cline { 1 - 3 }
\end{array} \\
& \text { Ca } 0.83 \quad 0.52 \\
& \begin{array}{l|l|l|}
\text { V.FINE.SILT } & 0.29 \\
\hline
\end{array}
\end{aligned}
$$

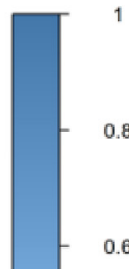

Figure 1. Pearson correlation matrix of geochemical and sedimentological parameters analysed from EN18208. Only p-values $<0.001$ were coloured.

organised field-work. Stuart Andrew Vyse obtained sub-bottom profiling data and was responsible for opening, splicing and subsampling the core as well as all geochemical (XRF) and sedimentological (TC, TN, TOC, grain-size, XRD) analyses and the age-depth modelling. He also wrote the first version of the manuscript. Andrei Andreev provided interpretation of pollen records. Boris Biskaborn contributed diatom data (benthic/planktonic ratios) and supervised the works of Stuart Andrew Vyse. Simon Armitage provided OSL dating. Bernhard Diekmann assisted in the interpretation of XRD data. All co-authors contributed to interpretation of the results and commented on the text.

\section{Acknowledgments}

This research has been supported by BMBF PALMOD (grant no. 01LP1510D), the ERC European Union's Horizon 2020 research and innovation programme (grant agreement no. 772852, Project. GlacialLegacy), the Initiative and Networking fund of the Helmholtz Association, as well as ESKP: Past permafrost sources. We acknowledge support by the Open Access Publication Funds of the Alfred Wegener Institute Helmholtz Centre for Polar and Marine Research. The authors would like to thank all members that participated in the Chukotka 2018 expedition. Moreover, we thank 
Tina Kollaske and Ulli Raschke (BGR-Spandau), Vladimir Rodatis (GFZ-Potsdam) and Rebecca Morawietz, Levent Vorpahl and Daria Kapustina (AWI-Potsdam). We thank the two anonymous reviewers whose comments/suggestions helped improve and clarify this manuscript.

\section{Appendix A. Supplementary data}

Supplementary data to this article can be found online at https://doi.org/10.1016/j.quascirev.2020.106607.

\section{References}

ACIA, 2004. Impacts of a Warming Arctic-Arctic Climate Impact Assessment. Cambridge University Press, Cambridge.

Aitchison, J., 1984. The statistical analysis of geochemical compositions. J. Int. Assoc. Math. Geol. 16, 531-564. https://doi.org/10.1007/BF01029316.

Amap, 2017. Snow, Water, Ice and Permafrost in the Arctic (SWIPA) 2017. Oslo.

Anderson, P.M., Bartlein, P.J., Brubaker, L.B., 1994. Late Quaternary history of tundra vegetation in northwestern Alaska. Quat. Res. 41, 306-315.

Anderson, P.M., Lozhkin, A.V., 2015. Late quaternary vegetation of Chukotka (northeast Russia), implications for glacial and Holocene environments of Beringia. Quat. Sci. Rev. 107, 112-128. https://doi.org/10.1016/ j.quascirev.2014.10.016.

Anderson, P.M., Lozhkin, A.V., 2001. The stage 3 interstadial complex (Karginskii/ middle Wisconian interval) of Beringia: variations in paleoenvironments and implications for paleoclimatic interpretations. Quat. Sci. Rev. 20, 93-125. https://doi.org/10.1016/S0277-3791(00)00129-3.

Anderson, P.M., Lozhkin, A.V., Solomatkina, T.B., Brown, T.A., 2010. Paleoclimatic implications of glacial and postglacial refugia for Pinus pumila in western Beringia. Quat. Res. 73, 269-276. https://doi.org/10.1016/j.yqres.2009.09.008.

Andreev, A.A., Morozova, E., Fedorov, G., Schirrmeister, L., Bobrov, A.A., Kienast, F., Schwamborn, G., 2012. Vegetation history of Central Chukotka deduced from permafrost paleoenvironmental records of the El'gygytgyn Impact Crater. Clim. Past Discuss 8, 1409-1441. https://doi.org/10.5194/cpd-8-1409-2012.

Andreev, A.A., Raschke, E., Vyse, S.A., Courtin, J., Biskaborn, B.K., Böhmer, T., StoofLeichsenring, K., Kruse, S., Pestryakova, L.A., Herzschuh, U., 2020. Late Glacial to Holocene Vegetation and Climate History of Northwestern Chukotka Deduced from Lakes Ilirney and Rauchuagytgyn Pollen Records.

Anselmetti, F.S., Ariztegui, D., De Batist, M., Catalina Gebhardt, A., Haberzettl, T., Niessen, F., Ohlendorf, C., Zolitschka, B., 2009. Environmental history of southern Patagonia unravelled by the seismic stratigraphy of Laguna Potrok Aike. Sedimentology 56, 873-892. https://doi.org/10.1111/j.13653091.2008.01002.x

Arnaud, F., Révillon, S., Debret, M., Revel, M., Chapron, E., Jacob, J., Giguet-Covex, C., Poulenard, J., Magny, M., 2012. Lake Bourget regional erosion patterns reconstruction reveals Holocene NW European Alps soil evolution and paleohydrology. Quat. Sci. Rev. 51, 81-92. https://doi.org/10.1016/ j.quascirev.2012.07.025.

Asikainen, C.A., Francus, P., Brigham-Grette, J., 2007. Sedimentology, clay mineralogy and grain-size as indicators of $65 \mathrm{ka}$ of climate change from El'gygytgyn Crater Lake, northeastern Siberia. J. Paleolimnol. 37, 105-122. https://doi.org/ 10.1007/s10933-006-9026-5.

Avnimelech, Y., Ritvo, G., Meijer, L., Kochba, M., 2001. Water content, organic carbon and dry bulk density in flooded sediments. Aquacult. Eng. 25, 25-33.

Bakke, J., Lie, øyvind, Nesje, A., Dahl, S.O., Paasche, ø, 2005. Utilizing physical sediment variability in glacier-fed lakes for continuous glacier reconstructions during the Holocene, northern Folgefonna, western Norway. Holocene 15, 161-176. https://doi.org/10.1191/0959683605h1797rp.

Balistrieri, L.S., Murray, J.W., Paul, B., 1992. The cycling of iron and manganese in the water column of Lake Sammamish. Washington. Limnol. Oceanogr. 37, 510-528. https://doi.org/10.4319/lo.1992.37.3.0510.

Battarbee, R.W., Jones, V.J., Flower, R.J., Cameron, N.G., Bennion, H., Carvalho, L., Juggins, S., 2001. Diatoms. In: Smol, J. (Ed.), Tracking Environmental Change Using Lake Sediments. Kluwer Academic Publishers, Dordrecht, pp. 155-202. https://doi.org/10.1007/0-306-47668-1_8.

Benson, L.V., May, H.M., Antweiler, R.C., Brinton, T.I., Kashgarian, M., Smoot, J.P., Lund, S.P., 1998. Continuous lake-sediment records of glaciation in the Sierra Nevada between 52,600 and 12,500 14C yr B.P. Quat. Res. 50, 113-127. https:// doi.org/10.1006/qres.1998.1993.

Bischoff, J.L., Menking, K.M., Fitts, J.P., Fitzpatrick, J.A., 1997. Climatic oscillations $10,000-155,000$ yr B.P. At Owens lake, California reflected in glacial rock flour abundance and lake salinity in core OL-92. Quat. Res. 48, 313-325. https:// doi.org/10.1006/qres.1997.1933.

Biskaborn, B.K., Herzschuh, U., Bolshiyanov, D., Savelieva, L., Diekmann, B., 2012. Environmental variability in northeastern Siberia during the last $\sim 13,300 \mathrm{yr}$ inferred from lake diatoms and sediment-geochemical parameters. Palaeogeogr. Palaeoclimatol. Palaeoecol. 329-330, 22-36. https://doi.org/10.1016/ j.palaeo.2012.02.003.

Biskaborn, B.K., Herzschuh, U., Bolshiyanov, D.Y., Schwamborn, G., Diekmann, B., 2013. Thermokarst processes and depositional events in a tundra lake, northeastern Siberia. Permafr. Periglac. Process. 24, 160-174. https://doi.org/ 10.1002/ppp.1769.

Biskaborn, B.K., Nazarova, L., Pestryakova, L.A., Syrykh, L., Funck, K., Meyer, H., Chapligin, B., Vyse, S., Gorodnichev, R., Zakharov, E., Wang, R., Schwamborn, G., Bailey, H.L., Diekmann, B., 2019a. Spatial distribution of environmental indicators in surface sediments of Lake Bolshoe Toko, Yakutia, Russia. Biogeosciences 16, 4023-4049. https://doi.org/10.5194/bg-16-4023-2019.

Biskaborn, B.K., Nazarova, L., Pestryakova, L.A., Syrykh, L., Funck, K., Meyer, H., Chapligin, B., Vyse, S., Gorodnichev, R., Zakharov, E., Wang, R., Schwamborn, G. Bailey, H.L., Diekmann, B., 2019b. Spatial distribution of environmental indicators in surface sediments of Lake Bolshoe Toko, Yakutia, Russia. Biogeosciences 16, 4023-4049. https://doi.org/10.5194/bg-16-4023-2019.

Biskaborn, B.K., Smith, S.L., Noetzli, J., Matthes, H., Vieira, G., Streletskiy, D.A. Schoeneich, P., Romanovsky, V.E., Lewkowicz, A.G., Abramov, A., Allard, M., Boike, J., Cable, W.L., Christiansen, H.H., Delaloye, R., Diekmann, B., Drozdov, D., Etzelmüller, B., Grosse, G., Guglielmin, M., Ingeman-Nielsen, T., Isaksen, K., Ishikawa, M., Johansson, M., Johannsson, H., Joo, A., Kaverin, D., Kholodov, A. Konstantinov, P., Kröger, T., Lambiel, C., Lanckman, J.P., Luo, D., Malkova, G., Meiklejohn, I., Moskalenko, N., Oliva, M., Phillips, M., Ramos, M., Sannel, A.B.K., Sergeev, D., Seybold, C., Skryabin, P., Vasiliev, A., Wu, Q., Yoshikawa, K., Zheleznyak, M., Lantuit, H., 2019c. Permafrost is warming at a global scale. Nat. Commun. 10 https://doi.org/10.1038/s41467-018-08240-4.

Blott, S.J., Pye, K., 2001. Gradistat: a grain size distribution and statistics package for the analysis of unconsolidated sediments. Earth Surf. Process. Landforms 26, 1237-1248. https://doi.org/10.1002/esp.261.

Bøtter-Jensen, L., Andersen, C.E., Duller, G.A.T., Murray, A.S., 2003. Developments in radiation, stimulation and observation facilities in luminescence measurements. In: Radiation Measurements. Elsevier Ltd, pp. 535-541. https://doi.org/ 10.1016/S1350-4487(03)00020-9.

Bouchard, F., Francus, P., Pienitz, R., Laurion, I., 2011. Sedimentology and geochemistry of thermokarst ponds in discontinuous permafrost, subarctic Quebec, Canada. J. Geophys. Res. 116.

Brigham-Grette, J., Gualtieri, L.M., Glushkova, O.Y., Hamilton, T.D., Mostoller, D., Kotov, A., 2003. Chlorine-36 and 14C chronology support a limited last glacial maximum across central Chukotka, northeastern Siberia, and no Beringian ice sheet. Quat. Res. 59, 386-398. https://doi.org/10.1016/S0033-5894(03)00058-9.

Briner, J.P., Kaufman, D.S., 2008. Late Pleistocene mountain glaciation in Alaska: key chronologies. J. Quat. Sci. 23, 659-670. https://doi.org/10.1002/jqs.1196.

Brown, E.T., Le Callonnec, L., German, C.R., 2000. Geochemical cycling of redoxsensitive metals in sediments from Lake Malawi: a diagnostic paleotracer for episodic changes in mixing depth. Geochem. Cosmochim. Acta 64, 3515-3523. https://doi.org/10.1016/S0016-7037(00)00460-9.

Brubaker, L.B., Anderson, P.M., Edwards, M.E., Lozhkin, A.V., 2005. Beringia as a glacial refugium for boreal trees and shrubs: new perspectives from mapped pollen data. J. Biogeogr. 32, 833-848.

Chawchai, S., Kylander, M.E., Chabangborn, A., Löwemark, L., Wohlfarth, B., 2016. Testing commonly used X-ray fluorescence core scanning-based proxies for organic-rich lake sediments and peat. Boreas 45, 180-189. https://doi.org/ 10.1111/bor.12145.

Chen, J., Wan, G., Zhang, D.D., Zhang, F., Huang, R., 2004. Environmental records of lacustrine sediments in different time scales: sediment grain size as an example. Sci. China Earth Sci. 47, 954-960. https://doi.org/10.1360/03yd0160.

Clift, P.D., Wan, S., Blusztajn, J., 2014. Reconstructing chemical weathering, physical erosion and monsoon intensity since $25 \mathrm{Ma}$ in the northern South China Sea: a review of competing proxies. Earth Sci. Rev. https://doi.org/10.1016/ j.earscirev.2014.01.002.

Cohen, A., 2003. Palaeolimnology: the History and Evolution of Lake Systems. Oxford University Press, Oxford.

Cohen, J., Screen, J.A., Furtado, J.C., Barlow, M., Whittleston, D., Coumou, D. Francis, J., Dethloff, K., Entekhabi, D., Overland, J., Jones, J., 2014. Recent Arctic amplification and extreme mid-latitude weather. Nat. Geosci. https://doi.org/ $10.1038 /$ ngeo2234.

Colman, S.M., Jones, G.A., Rubin, M., King, J.W., Peck, J.A., Orem, W.H., 1996. AMS radiocarbon analyses from Lake Baikal, Siberia: challenges of dating sediments from a large, oligotrophic lake. Quat. Sci. Rev. 15, 669-684. https://doi.org/ 10.1016/0277-3791(96)00027-3.

Colquhoun, D., 2014. An investigation of the false discovery rate and the misinterpretation of p-values. R. Soc. open Sci. 1 https://doi.org/10.1098/rsos.140216.

Croudace, I., Rindby, A., Rothwell, G., 2006. ITRAX: description and evaluation of a new multi-function X-ray core scanner. Geol. Soc. Spec. Publ. 267, 51-63. https://doi.org/10.1144/GSL.SP.2006.267.01.04.

Croudace, I., Rothwell, G., 2015. Micro-XRF Studies of Sediment Cores: Applications of a Non-destructive Tool for the Environmental Sciences (Developments in Paleoenvironmental Research), Tracking Environmental Change Using Lake Sediments, vol. 2. Physical and Geochemical Methods. Springer Netherlands. https://doi.org/10.1007/978-94-017-9849-5.

Crump, S.E., Miller, G.H., Power, M., Sepúlveda, J., Dildar, N., Coghlan, M., Bunce, M., 2019. Arctic shrub colonization lagged peak postglacial warmth: molecular evidence in lake sediment from Arctic Canada. Global Change Biol. 25, 4244-4256. https://doi.org/10.1111/gcb.14836.

Cuven, S., Francus, P., Lamoureux, S.F., 2010. Estimation of grain size variability with micro X-ray fluorescence in laminated lacustrine sediments, Cape Bounty, Canadian high Arctic. J. Paleolimnol. 44, 803-817. https://doi.org/10.1007/s10933010-9453-1.

Davison, W., 1993. Iron and manganese in lakes. Earth Sci. Rev. 34, 119-163. https:// 
doi.org/10.1016/0012-8252(93)90029-7.

Dean, W.E., 1997. Rates, timing, and cyclicity of Holocene eolian activity in northcentral United States: evidence from varved lake sediments. Geology 25, $331-334$. RTACOH $>2.3 . \mathrm{CO} ; 2$

Diekmann, B., Hofmann, J., Henrich, R., Fütterer, D.K., Röhl, U., Wei, K.Y., 2008. Detrital sediment supply in the southern Okinawa Trough and its relation to sea-level and Kuroshio dynamics during the late Quaternary. Mar. Geol. 255, 83-95. https://doi.org/10.1016/j.margeo.2008.08.001.

Diekmann, B., Pestryakova, L., Nazarova, L., Subetto, D., Tarasov, P., Stauch, G., Thiemann, A., Lehmkuhl, F., Biskaborn, B., Kuhn, G., Henning, D., Müller, S., 2016. Late Quaternary lake dynamics in the Verkhoyansk Mountains of eastern Siberia: implications for climate and glaciation history. Polarforschung 86 , 97-110. https://doi.org/10.2312/polarforschung.86.2.97.

Dietze, E., Hartmann, K., Diekmann, B., IJmker, J., Lehmkuhl, F., Opitz, S., Stauch, G., Wünnemann, B., Borchers, A., 2012. An end-member algorithm for deciphering modern detrital processes from lake sediments of Lake Donggi Cona, NE Tibetan Plateau. China. Sediment. Geol. 243-244, 169-180. https://doi.org/10.1016/ j.sedgeo.2011.09.014

Dietze, E., Wegener, A., Hartmann, K., Lehmkuhl, F., Opitz, S., Diekmann, B., Ijmker, J., Stauch, G., Wünnemann, B., Borchers, A., 2011. An end-member algorithm for deciphering modern detrital processes from lake sediments of Lake Donggi Cona, NE Tibetan Plateau. China. Sediment. Geol. 243-244, 169-180. https:// doi.org/10.1016/j.sedgeo.2011.09.014.

Edwards, M.E., Brubaker, L.B., Lozhkin, A.V., Anderson, P.M., 2005. Structurally novel biomes: a response to past warming in Beringa. Ecology 86, 1696-1703.

Ehlers, J., Gibbard, P., Hughes, P., 2018. Quaternary glaciations and chronology. In: Menzies, J., van der Meer, J. (Eds.), Past Glacial Environments. Elsevier, pp. 77-101.

Ehlers, J., Gibbard, P.L., Hughes, P.D., 2011. Quaternary Glaciations - Extent and Chronology, first ed. Elsevier.

Elias, S.A., Brigham-Grette, J., 2013. Late Pleistocene glacial events in Beringia. In: Elias, S.A. (Ed.), Encyclopedia of Quaternary Science, second ed. Elsevier, Amsterdam, pp. 191-201. https://doi.org/10.1016/B978-0-444-53643-3.00116-

Engstrom, D., Hansen, B., 1985. Postglacial vegetational change and soil development in southeastern Labrador as inferred from pollen and chemical stratigraphy. Can. J. Bot. 543-561.

Fedorov, G., Andreev, A.A., Raschke, E., Wennrich, V., Schwamborn, G., Glushkova, O.Y., Juschus, O., Zander, A., Melles, M., 2019. Middle to Late Pleistocene lake-level fluctuations of Lake El'gygytgyn, far-east Russian Arctic. Boreas 48, 516-533. https://doi.org/10.1111/bor.12367.

Fedotov, A.P., Phedorin, M.A., Enushchenko, I.V., Vershinin, K.E., Melgunov, M.S., Khodzher, T.V., 2012. A reconstruction of the thawing of the permafrost during the last 170 years on the Taimyr Peninsula (East Siberia, Russia). Glob. Planet. Change 98-99, 139-152. https://doi.org/10.1016/j.gloplacha.2012.09.002.

Flood, R.P., Bloemsma, M.R., Weltje, G.J., Barr, I.D., O'Rourke, S.M., Turner, J.N., Orford, J.D., 2016. Compositional data analysis of Holocene sediments from the West Bengal Sundarbans, India: geochemical proxies for grain-size variability in a delta environment. Appl. Geochem. 75, 222-235. https://doi.org/10.1016/ j.apgeochem.2016.06.006.

Fritz, S.C., Anderson, N.J., 2013. The relative influences of climate and catchment processes on Holocene lake development in glaciated regions. J. Paleolimnol. 49, 349-362. https://doi.org/10.1007/s10933-013-9684-z.

Fujita, K., Mackey, K., McCaleb, R., Gunbina, L., Valentin, K., Imaev, V., Smirnov, V. 2002. Seismicity of Chukotka, northeastern Russia. Geol. Soc. Am. Spec. Pap. $360,259-272$.

Glushkova, O.Y., 2011. Late Pleistocene glaciations in north-east asia. In: Ehlers, Jürgen, Philip, L., Gibbard, P.D.H. (Eds.), Quaternary Glaciations - Extent and Chronology. Elsevier, pp. 865-875. https://doi.org/10.1016/B978-0-44453447-7.00063-5.

Glushkova, O.Y., Smirnov, V.N., 2007. Pliocene to Holocene geomorphic evolution and paleogeography of the El'gygytgyn Lake region, NE Russia. J. Paleolimnol. 37, 37-47. https://doi.org/10.1007/s10933-006-9021-x.

Grimm, E.C., 1987. CONISS: a FORTRAN 77 program for stratigraphically constrained cluster analysis by the method of incremental sum of squares. Comput. Geosci. 13, 13-35. https://doi.org/10.1016/0098-3004(87)90022-7.

Grotheer, H., Meyer, V., Riedel, T., Pfalz, G., Mathieu, L., Hefter, J., Gentz, T., Lantuit, H., Mollenhauer, G., Fritz, M., 2020. Burial and origin of permafrostderived carbon in the nearshore zone of the southern Canadian beaufort sea. Geophys. Res. Lett. 47 https://doi.org/10.1029/2019GL085897.

Gualtieri, L., Glushkova, O., Brigham-Grette, J., 2000. Evidence for restricted ice extent during the last glacial maximum in the Koryak Mountains of Chukotka, Far Eastern Russia. Bull. Geol. Soc. Am. 112, 1106-1118. https://doi.org/10.1130/ 0016-7606(2000)112<1106:EFRIED>2.0.CO;2.

Hamilton, T., Ashley, G., 1993. Epiguruk: a late Quaternary environmental record from northwestern Alaska. GSA Bull 105, 583-602. https://doi.org/10.1130/ 0016-7606(1993)105<0583:ealqer>2.3.co;2.

Hamilton, T.D., 2001. Quaternary glacial, lacustrine, and fluvial interactions in the western Noatak basin, Northwest Alaska. Quat. Sci. Rev. 20, 371-391. https:// doi.org/10.1016/S0277-3791(00)00110-4.

Hamilton, T.D., Reed, K.M., Thorson, R.M., 1986. Late cenozoic glaciation of the central Brooks range. In: Hamilton, T.D., Reed, K.M., Thorson, R.M. (Eds.), Glaciation in Alaska: the Geologic Record. Alaska Geological Society, pp. 9-49. Heinecke, L., Mischke, S., Adler, K., Barth, A., Biskaborn, B.K., Plessen, B., Nitze, I.,
Kuhn, G., Rajabov, I., Herzschuh, U., 2017. Climatic and limnological changes at Lake Karakul (Tajikistan) during the last 29 cal ka. J. Paleolimnol. 58, 317-334. https://doi.org/10.1007/s10933-017-9980-0.

Heinsalu, A., Luup, H., Alliksaar, T., Nõges, P., Nõges, T., 2007. Water level changes in a large shallow lake as reflected by the plankton:periphyton-ratio of sedimentary diatoms. In: Nõges, T. (Ed.), European Large Lakes Ecosystem Changes and Their Ecological and Socioeconomic Impacts. Springer Netherlands, pp. 23-30. https://doi.org/10.1007/978-1-4020-8379-2_3.

Heiser, P.A., Roush, J.J., 2001. Pleistocene glaciations in Chukotka, Russia: moraine mapping using satellite synthetic aperture radar (SAR) imagery. Quat. Sci. Rev. 20, 393-404. https://doi.org/10.1016/S0277-3791(00)00109-8.

Herzschuh, U., Birks, H.J.B., Laepple, T., Andreev, A., Melles, M., Brigham-Grette, J. 2016. Glacial legacies on interglacial vegetation at the Pliocene-Pleistocene transition in NE Asia. Nat. Commun. 7, 1-11. https://doi.org/10.1038/ ncomms 11967.

Hope, C., Schaefer, K., 2016. Economic impacts of carbon dioxide and methane released from thawing permafrost. Nat. Clim. Change 6, 56-59. https://doi.org/ 10.1038/nclimate2807.

Hughes, O., 1983. Quaternary geology, yukon territory and western district of mackenzie. In: Thorson, R.M., Hamilton, T.D. (Eds.), Glaciation in Alaska. Fairbanks, pp. 51-56.

IPCC, 2019. Climate Change and Land: an IPCC special report on climate change, desertification, land degradation, sustainable land management, food security, and greenhouse gas fluxes in terrestrial ecosystems. In: Shukla, P., Skea, J., Calvo Buendia, E., Masson-Delmotte, V., Pörtner, H., Roberts, D., Zhai, P., Slade, R., Connors, S., van Diemen, R., Ferrat, M., Haughey, E., Luz, S., Neogi, S., Pathak, M., Petzold, J., Portugal Pereira, J., Vyas, P., Huntley, E., Kissick, K., Bel, M., Malley, J. (Eds.). IPCC, 2019

Ispolatov, V.O., Tikhomirov, P.L., Heizler, M., Cherepanova, I.Y., 2004. New 40Ar/39Ar ages of cretaceous continental volcanics from Central Chukotka: implications for initiation and duration of volcanism within the northern part of the Okhotsk Chukotka volcanic belt (northeastern Eurasia). J. Geol. 112, 369-377. https:// doi.org/10.1086/382765.

Johnson, D.P., Searle, D.E., Hopley, D., 1982. Positive relief over buried post-glacial channels, Great barrier reef province, Australia. Mar. Geol. 46, 149-159. https://doi.org/10.1016/0025-3227(82)90156-6.

Juschus, O., Melles, M., Gebhart, A., Niessen, F., 2009. Late quaternary mass movement events in lake El'gygytgyn, north-eastern siberia. Sedimentology 56, 2155-2174. https://doi.org/10.1111/j.1365-3091.2009.01074.x.

Juschus, O., Pavlov, M., Schwamborn, G., Preusser, F., Fedorov, G., Melles, M., 2011. Late quaternary Lake-level changes of lake el'gygytgyn, NE siberia. Quat. Res. 76, 441-451. https://doi.org/10.1016/j.yqres.2011.06.010.

Kalugin, I., Daryin, A., Smolyaninova, L., Andreev, A., Diekmann, B., Khlystov, O., 2007. 800-yr-long records of annual air temperature and precipitation over southern Siberia inferred from Teletskoye Lake sediments. Quat. Res. 67, 400-410. https://doi.org/10.1016/j.yqres.2007.01.007.

Karlén, W., 1981. Lacustrine sediment studies. Geogr. Ann. Ser. A, Phys. Geogr. 63, 273-281. https://doi.org/10.1080/04353676.1981.11880042.

Kokorowski, H.D., Anderson, P.M., Mock, C.J., Lozhkin, A.V., 2008. A re-evaluation and spatial analysis of evidence for a Younger Dryas climatic reversal in Beringia. Quat. Sci. Rev. 27, 1710-1722. https://doi.org/10.1016/ j.quascirev.2008.06.010.

Kruse, S., Bolshiyanov, D., Grigoriev, M.N., Morgenstern, A., Pestryakova, L. Tsibizov, B., Ludke, A., 2019. Russian-German cooperation: expeditions to siberia in 2018. Reports polar Mar. Res. 734, 263, 0.

Kylander, M.E., Ampel, L., Wohlfarth, B., Veres, D., 2011. High-resolution X-ray fluorescence core scanning analysis of Les Echets (France) sedimentary sequence: new insights from chemical proxies. J. Quat. Sci. 26, 109-117. https:// doi.org/10.1002/jqs.1438.

Labuhn, I., Hammarlund, D., Chapron, E., Czymzik, M., Dumoulin, J.-P., Nilsson, A., Régnier, E., Robygd, J., von Grafenstein, U., 2018. Holocene hydroclimate variability in central Scandinavia inferred from flood layers in contourite drift deposits in Lake Storsjön. Quaternary 1, 2. https://doi.org/10.3390/quat1010002.

Lapointe, E., Talbot, J., Fortier, D., Fréchette, B., Strauss, J., Kanevskiy, M., Shur, Y., 2017. Middle to Late Wisconsinan climate and ecological changes in northern Alaska: evidences from the Itkillik River yedoma. Palaeogeogr. Palaeoclimatol. Palaeoecol. 485, 906-916. https://doi.org/10.1016/j.palaeo.2017.08.006.

Lebas, E., Krastel, S., Wagner, B., Gromig, R., Fedorov, G., Baumer, M., Kostromina, N., Haflidason, H., 2019. Seismic stratigraphical record of Lake Levinson-Lessing Taymyr Peninsula: evidence for ice-sheet dynamics and lake-level fluctuations since the Early Weichselian. Boreas 48, 470-487. https://doi.org/10.1111/ bor.12381.

Lehmkuhl, F., Haselein, F., 2000. Quaternary paleoenvironmental change on the Tibetan Plateau and adjacent areas (Western China and Western Mongolia). Quat. Int. 65-66, 121-145. https://doi.org/10.1016/S1040-6182(99)00040-3.

Lenz, J., Jones, B.M., Wetterich, S., Tjallingii, R., Fritz, M., Arp, C.D., Rudaya, N., Grosse, G., 2016. Impacts of Shore Expansion and Catchment Characteristics on Lacustrine Thermokarst Records in Permafrost Lowlands, Alaska Arctic Coastal Plain. https://doi.org/10.1007/s41063-016-0025-0. Arktos 2.

Liu, X., Herzschuh, U., Wang, Y., Kuhn, G., Yu, Z., 2014. Glacier fluctuations of Muztagh Ata and temperature changes during the late Holocene in westernmost Tibetan Plateau, based on glaciolacustrine sediment records. Geophys. Res. Lett. 41, 6265-6273. https://doi.org/10.1002/2014GL060444.

Loizeau, J.L., Span, D., Coppee, V., Dominik, J., 2001. Evolution of the trophic state of Lake Annecy (eastern France) since the last glaciation as indicated by iron, 
manganese and phosphorus speciation. J. Paleolimnol. 25, 205-214. https:// doi.org/10.1023/A:1008100432461.

Lougheed, B.C., Obrochta, S.P., 2019. A rapid, deterministic age-depth modeling routine for geological sequences with inherent depth uncertainty. Paleoceanogr. Paleoclimatology 34, 122-133. https://doi.org/10.1029/2018PA003457.

Löwemark, L., Chen, H.F., Yang, T.N., Kylander, M., Yu, E.F., Hsu, Y.W., Lee, T.Q., Song, S.R., Jarvis, S., 2011. Normalizing XRF-scanner data: a cautionary note on the interpretation of high-resolution records from organic-rich lakes. J. Asian Earth Sci. 40, 1250-1256. https://doi.org/10.1016/j.jseaes.2010.06.002.

Lozhkin, A.V., Anderson, P.M., Minyuk, P., Korzun, J., Brown, T., Pakhomov, A., Tsygankova, V., Burnatny, S., Naumov, A., 2018. Implications for conifer glacial refugia and postglacial climatic variation in western Beringia from lake sediments of the Upper Indigirka basin. Boreas 47, 938-953. https://doi.org/10.1111/ bor.12316.

Lozhkin, A.V., Anderson, P.M., 2013. Late quaternary lake records from the Anadyr lowland, central Chukotka (Russia). Quat. Sci. Rev. 68, 1-16. https://doi.org/ 10.1016/j.quascirev.2013.02.007.

Lozhkin, A.V., Anderson, P.M., 2011. Forest or no forest: implications of the vegetation record for climatic stability in western Beringia during oxygen isotope stage 3. Quat. Sci. Rev. 30, 2160-2181. https://doi.org/10.1016/ j.quascirev.2010.12.022.

Lozhkin, A.V., Anderson, P.M., 2006. A reconstruction of the climate and vegetation of northeastern Siberia based on lake sediments. Paleontol. J. 40 https://doi.org/ 10.1134/S0031030106110098.

Lozhkin, A.V., Anderson, P.M., Vartanyan, S.L., Brown, T.A., Belaya, B.V., Kotov, A.N., 2001. Late quaternary paleoenvironments and modern pollen data from Wrangel Island (northern Chukotka). Quat. Sci. Rev. 20, 217-233. https:// doi.org/10.1016/S0277-3791(00)00121-9.

Lozhkin, A.V., Anderson, P.M., Matrosova, T.V., Minyuk, P.S., Brigham-Grette, J., Melles, M., 2007. Continuous record of environmental changes in Chukotka during the last 350 thousand years. Russ. J. Pacific Geol. 1, 550-555. https:// doi.org/10.1134/S1819714007060048.

Lozhkin, A.V., Brown, T.A., Anderson, P.M., Glushkova, O.Y., Melekestsev, I.V., 2016. The importance of radiocarbon dates and tephra for developing chronologies of Holocene environmental changes from lake sediments, North Far East. Russ. J. Pacific Geol. 10, 249-262. https://doi.org/10.1134/S1819714016040047.

Mahaney, W.C., 2011. SEM analysis of glacial sediments. In: Singh, V., Singh, P., Haritashya, U. (Eds.), Encyclopedia of Snow, Ice and Glaciers. Encyclopedia of Earth Sciences Series. Springer Netherlands, pp. 1016-1027. https://doi.org/ 10.1007/978-90-481-2642-2_651.

Marshall, M.H., Lamb, H.F., Huws, D., Davies, S.J., Bates, R., Bloemendal, J., Boyle, J., Leng, M.J., Umer, M., Bryant, C., 2011. Late Pleistocene and Holocene drought events at lake tana, the source of the blue nile. Global Planet. Change 78, 147-161. https://doi.org/10.1016/j.gloplacha.2011.06.004.

Melles, M., Brigham-Grette, J., Glushkova, O.Y., Minyuk, P.S., Nowaczyk, N.R., Hubberten, H.W., 2007. Sedimentary geochemistry of core PG1351 from Lake El'gygytgyn-a sensitive record of climate variability in the East Siberian Arctic during the past three glacial-interglacial cycles. J. Paleolimnol. 37, 89-104. https://doi.org/10.1007/s10933-006-9025-6.

Melles, M., Brigham-Grette, J., Minyuk, P.S., Nowaczyk, N.R., Wennrich, V., DeConto, R.M., Anderson, P.M., Andreev, A.A., Coletti, A., Cook, T.L., HaltiaHovi, E., Kukkonen, M., Lozhkin, A.V., Rosén, P., Tarasov, P., Vogel, H., Wagner, B., 2012. 2.8 Million years of arctic climate change from Lake El'gygytgyn, NE Russia. Science 84 337, 315-320. https://doi.org/10.1126/science.1222135.

Melles, M., Minyuk, P., Brigham-Grette, J., 2005. The Expedition El'gygytgyn Lake 2003 (Siberian Arctic), Reports on Polar and Marine Research.

Meyers, P.A., Lallier-Vergès, E., 1999. Lacustrine sedimentary organic matter records of Late Quaternary paleoclimates. J. Paleolimnol. 21, 345-372. https://doi.org/ 10.1023/A: 1008073732192.

Meyers, P.A., Teranes, J.L., 2005. Sediment organic matter. In: Smol, J. (Ed.), Tracking Environmental Change Using Lake Sediments. Kluwer Academic Publishers, Dordrecht, pp. 239-269. https://doi.org/101007/0-306-47670-3 9.

Minyuk, P.S., Brigham-Grette, J., Melles, M., Borkhodoev, V.Y., Glushkova, O.Y., 2007. Inorganic geochemistry of El'gygytgyn Lake sediments (northeastern Russia) as an indicator of paleoclimatic change for the last 250 kyr. J. Paleolimnol. 37, 123-133. https://doi.org/10.1007/s10933-006-9027-4.

Morin, P., Porter, C., Cloutier, M., Howat, I., Noh, M.-J., Willis, M., Bates, B., Willamson, C., Peterman, K., 2016. ArcticDEM; A publicly available, high resolution elevation model of the Arctic. In: Geophysical Research Abstracts. Vienna, pp. 2016-8396.

Müller, S., Tarasov, P.E., Andreev, A.A., Tütken, T., Gartz, S., Diekmann, B., 2010. Late Quaternary vegetation and environments in the Verkhoyansk Mountains region (NE Asia) reconstructed from a 50-kyr fossil pollen record from Lake Billyakh. Quat. Sci. Rev. 29, 2071-2086. https://doi.org/10.1016/j.quascirev.2010.04.024.

Murray, A.S., Wintle, A.G., 2000. Luminescence dating of quartz using an improved single-aliquot regenerative-dose protocol. Radiat. Meas. 32, 57-73. https:// doi.org/10.1016/S1350-4487(99)00253-X.

Naeher, S., Gilli, A., North, R.P., Hamann, Y., Schubert, C.J., 2013. Tracing bottom water oxygenation with sedimentary $\mathrm{Mn} / \mathrm{Fe}$ ratios in Lake Zurich, Switzerland. Chem. Geol. 352, 125-133. https://doi.org/10.1016/j.chemgeo.2013.06.006.

Nealson, K.H., 1997. Sediment bacteria: who's there, what are they doing, and what's new? Annu. Rev. Earth Planet Sci. 25, 403-434. https://doi.org/10.1146/ annurev.earth.25.1.403.

Nesbitt, H., Young, G., 1996. Petrogenesis of sediments in the absence of chemical weathering: effects of abrasion and sorting on bulk composition and mineralogy. Sedimentology 43, 341-358. https://doi.org/10.1046/j.13653091.1996.d01-12.x.

Nolan, M., Brigham-Grette, J., 2007. Basic hydrology, limnology, and meteorology of modern Lake El'gygytgyn, Siberia. J. Paleolimnol. 37, 17-35. https://doi.org/ 10.1007/s10933-006-9020-y.

Nowaczyk, N., Melles, M., Minyuk, P., 2007. A revised age model for core PG1351 from Lake El'gygytgyn, Chukotka, based on magnetic susceptibility variations tuned to northern hemisphere insolation variations. J. Paleolimnol. 37, 65-76.

Odegaard, C., Rea, D.K., Moore, T.C., 2003. Stratigraphy of the mid-Holocene black bands in Lakes Michigan and Huron: evidence for possible basin-wide anoxia. J. Paleolimnol. 29, 221-234. https://doi.org/10.1023/A:1023239908588.

Opitz, S., Wünnemann, B., Aichner, B., Dietze, E., Hartmann, K., Herzschuh, U., Ijmker, J., Lehmkuhl, F., Li, S., Mischke, S., Plotzki, A., Stauch, G., Diekmann, B., 2012. Late glacial and Holocene development of lake donggi cona, northeastern Tibetan plateau, inferred from sedimentological analysis. Palaeogeogr. Palaeoclimatol. Palaeoecol. 337-338, 159-176. https://doi.org/10.1016/ j.palaeo.2012.04.013.

Pattan, J.N., 1993. Manganese micronodules: a possible indicator of sedimentary environments. Mar. Geol. 113, 331-344. https://doi.org/10.1016/0025-3227(93) 90026-R.

Peinerud, E.K., 2000. Interpretation of Si concentrations in lake sediments: three case studies. Environ. Geol. 40, 64-72. https://doi.org/10.1007/PL00013330.

Peros, M.C., Gajewski, K., 2008. Testing the reliability of pollen-based diversity estimates. J. Paleolimnol. 40, 357-368. https://doi.org/10.1007/s10933-007-91662 .

Petschick, R., 2002. MacDiff 4.2.6.

Pitkänen, H., Lehtoranta, J., Räike, A., 2001. Internal nutrient fluxes counteract decreases in external load: the case of the estuarial eastern Gulf of Finland, Baltic Sea. AMBIO A J. Hum. Environ. 30, 195-201. https://doi.org/10.1579/0044-7447 30.4.195.

Prescott, J.R., Hutton, J.T., 1988. Cosmic ray and gamma ray dosimetry for TL and ESR. Int. J. Radiat. Appl. Instrumentation. Part 14, 223-227. https://doi.org/ 10.1016/1359-0189(88)90069-6.

Prins, M.A., Weltje, G.J., 1999. End-member modeling of siliciclastic grain-size distributions: the late Quaternary record of eolian and fluvial Sediment supply to the Arabian Sea and its paleoclimatic significance. Math. Geol. 29, 503-549.

Priscu, J.C., Fritsen, C.H., Adams, E.E., Giovannoni, S.J., Paerl, H.W., McKay, C.P., Doran, P.T., Gordon, D.A., Lanoil, B.D., Pinckney, J.L., 1998. Perennial antarctic lake ice: an oasis for life in a polar desert. Science 80 (280), 2095-2098. https:// doi.org/10.1126/science.280.5372.2095.

Prokopenko, A.A., Williams, D.F., Karabanov, E.B., Khursevich, G.K., 2001. Continental response to heinrich events and bond cycles in sedimentary record of lake baikal, siberia. Global Planet. Change 28, 217-226. https://doi.org/10.1016/ S0921-8181(00)00074-6.

Reimer, P.J., Bard, E., Bayliss, A., Beck, J.W., Blackwell, P.G., Ramsey, C.B., Buck, C.E., Cheng, H., Edwards, R.L., Friedrich, M., Grootes, P.M., Guilderson, T.P., Haflidason, H., Hajdas, I., Hatté, C., Heaton, T.J., Hoffmann, D.L., Hogg, A.G. Hughen, K.A., Kaiser, K.F., Kromer, B., Manning, S.W., Niu, M., Reimer, R.W., Richards, D.A., Scott, E.M., Southon, J.R., Staff, R.A., Turney, C.S.M., van der Plicht, J., 2013. IntCal13 and marine13 radiocarbon age calibration curves 0-50,000 years cal BP. Radiocarbon 55, 1869-1887. https://doi.org/10.2458/ azu_js_rc.55.16947.

Rothe, M., Kleeberg, A., Hupfer, M., 2016. The occurrence, identification and environmental relevance of vivianite in waterlogged soils and aquatic sediments Earth Sci. Rev. 158, 51-64.

Saulnier-Talbot, É., Gregory-Eaves, I., Simpson, K.G., Efitre, J., Nowlan, T.E., Taranu, Z.E., Chapman, L.J., 2014. Small changes in climate can profoundly alter the dynamics and ecosystem services of tropical crater lakes. PloS One 9. https://doi.org/10.1371/journal.pone.0086561.

Schirrmeister, L., Siegert, C., Kuznetsova, T., Kuzmina, S., Andreev, A., Kienast, F., Meyer, H., Bobrov, A., 2002. Paleoenvironmental and paleoclimatic records from permafrost deposits in the Arctic region of Northern Siberia. Quat. Int. 89, 97-118.

Shakun, J.D., Clark, P.U., He, F., Lifton, N.A., Liu, Z., Otto-Bliesner, B.L., 2015. Regional and global forcing of glacier retreat during the last deglaciation. Nat. Commun. 6, 8059. https://doi.org/10.1038/ncomms9059.

Smol, J., 1988. Palaeoclimate proxy data from freshwater arctic diatoms. Verhandlungen der Int. Vereinigung von Limnol. 23, 837-844.

Stauch, G., Gualtieri, L., 2008. Late Quaternary glaciations in northeastern Russia. J. Quat. Sci. 23, 545-558. https://doi.org/10.1002/jqs.1211.

Stevens, L.R., Stone, J.R., Campbell, J., Fritz, S.C., 2006. A $2200-y r$ record of hydrologic variability from Foy Lake, Montana, USA, inferred from diatom and geochemical data. Quat. Res. 65, 264-274. https://doi.org/10.1016/j.yqres.2005.08.024.

Stewart, M.A., Lonergan, L., 2011. Seven glacial cycles in the middle-late Pleistocene of northwest Europe: geomorphic evidence from buried tunnel valleys. Geology 39, 283-286. https://doi.org/10.1130/G31631.1.

Stockmarr, J., 1971. Tablets with spores used in absolute pollen analysis. Pollen Spores 13, 614-621.

Synal, H.A., Stocker, M., Suter, M., 2007. MICADAS: a new compact radiocarbon AMS system. Nucl. Instrum. Methods Phys. Res. Sect. B Beam Interact. Mater. Atoms 259, 7-13. https://doi.org/10.1016/j.nimb.2007.01.138.

Team, R.C., 2019. R: a language and environment for statistical computing. R Core Team.

Terry, R., Chilingar, G., 1955. Summary of "Concerning some additional aids in studying sedimentary formations. J. Sediment. Petrol. 229-234. 
Thöle, H., Bornemann, A., Heimhofer, U., Luppold, F.W., Blumenberg, M., Dohrmann, R., Erbacher, J., 2019. Using high-resolution XRF analyses as a sequence stratigraphic tool in a mudstone-dominated succession (Early Cretaceous, Lower Saxony Basin, Northern Germany). Depos. Rec. dep2. 83 https:// doi.org/10.1002/dep2.83.

Tjallingii, R., Röhl, U., Kölling, M., Bickert, T., 2007. Influence of the water content on $\mathrm{X}$-ray fluorescence core-scanning measurements in soft marine sediments. Gcubed 8. https://doi.org/10.1029/2006GC001393 n/a-n/a.

Vandenberghe, J., 2013. Grain size of fine-grained windblown sediment: a powerful proxy for process identification. Earth Sci. Rev. https://doi.org/10.1016/ j.earscirev.2013.03.001.

Vologina, E., Granin, N., Lomonosova, T., Vorobyeva, S., Kulikova, N., Kalashnikova, I., Granina, L., 2003. Input of Silt-Sand Material to the Central Part of Southern Lake Baikal by Ice Transportation. BAIK-SED-2.

Wacker, L., Bonani, G., Friedrich, M., Hajdas, I., Kromer, B., Němec, M., Ruff, M., Suter, M., Synal, H.A., Vockenhuber, C., 2010. MICADAS: routine and highprecision radiocarbon dating. Radiocarbon 52, 252-262. https://doi.org/ 10.1017/S0033822200045288.

Wang, R., Zhang, Y., Wünnemann, B., Biskaborn, B.K., Yin, H., Xia, F., Zhou, L., Diekmann, B., 2015. Linkages between Quaternary climate change and sedimentary processes in Hala Lake, northern Tibetan Plateau, China. J. Asian Earth Sci. 107, 140-150. https://doi.org/10.1016/j.jseaes.2015.04.008.

Wang, W., Ma, Y., Feng, Z., Narantsetseg, T., Liu, K.B., Zhai, X., 2011. A prolonged dry mid-Holocene climate revealed by pollen and diatom records from Lake Ugii Nuur in central Mongolia. Quat. Int. 229, 74-83. https://doi.org/10.1016/ j.quaint.2010.06.005.

Wei, T., Simko, V., 2017. R Package "Corrplot": Visualization of a Correlation Matrix.

Weltje, G.J., Tjallingii, R., 2008. Calibration of XRF core scanners for quantitative geochemical logging of sediment cores: theory and application. Earth Planet Sci. Lett. 274, 423-438. https://doi.org/10.1016/j.epsl.2008.07.054.

Wersin, P., Höhener, P., Giovanoli, R., Stumm, W., 1991. Early diagenetic influences on iron transformations in a freshwater lake sediment. Chem. Geol. 90, 233-252. https://doi.org/10.1016/0009-2541(91)90102-W.

Wetterich, S., Kuzmina, S., Andreev, A.A., Kienast, F., Meyer, H., Schirrmeister, L.,
Kuznetsova, T., Sierralta, M., 2008. Palaeoenvironmental dynamics inferred from late quaternary permafrost deposits on kurungnakh Island, Lena delta northeast siberia, Russia. Quat. Sci. Rev. 27, 1523-1540. https://doi.org/10.1016/ j.quascirev.2008.04.007.

Wetterich, S., Rudaya, N., Tumskoy, V., Andreev, A.A., Opel, T., Schirrmeister, L. Meyer, H., 2011. Last glacial maximum records in permafrost of the east siberian arctic. Quat. Sci. Rev. 30, 3139-3151. https://doi.org/10.1016/ j.quascirev.2011.07.020.

Wetterich, S., Tumskoy, V., Rudaya, N., Andreev, A.A., Opel, T., Meyer, H., Schirrmeister, L., Hüls, M., 2014. Ice complex formation in arctic east siberia during the MIS3 interstadial. Quat. Sci. Rev. 84, 39-55. https://doi.org/10.1016/ j.quascirev.2013.11.009.

Wolin, J.A., Stone, J.R., 2010. Diatoms as Indicators of Water-Level Change in Freshwater Lakes. Cambridge University Press.

Wunderlich, J., Müller, S., 2003. High-resolution sub-bottom profiling using parametric acoustics. Int. Ocean Syst. 7, 6-11.

Wünnemann, B., Reinhardt, C., Kotlia, B.S., Riedel, F., 2008. Observations on the relationship between lake formation, permafrost activity and lithalsa development during the last 20000 years in the Tso Kar basin, Ladakh, India. Permafr. Periglac. Process. 19, 341-358. https://doi.org/10.1002/ppp.631.

Yamada, K., 2004. Last 40 ka climate changes as deduced from the lacustrine sediments of Lake Biwa, central Japan. Quat. Int. 123-125, 43-50. https://doi.org/ 10.1016/j.quaint.2004.02.007.

Zander, A., Hilgers, A., 2013. Potential and limits of OSL, TT-OSL, IRSL and pIRIR 290 dating methods applied on a Middle Pleistocene sediment record of Lake El'gygytgyn, Russia. Clim. Past 9, 719-733. https://doi.org/10.5194/cp-9-7192013.

Zhuravlev, G.F., Kazymin, S.S., Pukalo, P.V., 1999. State Geological Map of the Russian Federation, Scale 1:200 000. Anjuyjsker-Chaunsker Series, Moscow (St. Petersburg).

Ziegler, M., Jilbert, T., de Lange, G.J., Lourens, L.J., Reichart, G.-J., 2008. Bromine counts from XRF scanning as an estimate of the marine organic carbon content of sediment cores. G-cubed 9, 1-6. https://doi.org/10.1029/2007GC001932. 